\title{
Structural, physiognomic and above-ground biomass variation in savanna-forest transition zones on three continents - how different are co-occurring savanna and forest formations?
}

\author{
E. M. Veenendaal ${ }^{1}$, M. Torello-Raventos ${ }^{2}$, T. R. Feldpausch ${ }^{3}$, T. F. Domingues ${ }^{4}$, F. Gerard ${ }^{5}$, F. Schrodt ${ }^{3}$, G. Saiz ${ }^{2,25}$, \\ C. A. Quesada ${ }^{3,6}$, G. Djagbletey ${ }^{7}$, A. Ford ${ }^{8}$, J. Kemp ${ }^{9}$, B. S. Marimon ${ }^{10}$, B. H. Marimon-Junior ${ }^{10}$, E. Lenza ${ }^{10}$, \\ J. A. Ratter ${ }^{11}$, L. Maracahipes $^{10}$, D. Sasaki ${ }^{12}$, B. Sonké ${ }^{13}$, L. Zapfack ${ }^{13}$, D. Villarroel $^{14}$, M. Schwarz ${ }^{15}$, \\ F. Yoko Ishida ${ }^{6,16}$, M. Gilpin ${ }^{3}$, G. B. Nardoto ${ }^{17}$, K. Affum-Baffoe ${ }^{18}$, L. Arroyo ${ }^{14}$, K. Bloomfield ${ }^{3}$, G. Ceca ${ }^{1}$, \\ H. Compaore ${ }^{19}$, K. Davies ${ }^{2}$, A. Diallo ${ }^{20}$, N. M. Fyllas ${ }^{3}$, J. Gignoux ${ }^{21}$, F. Hien ${ }^{20}$, M. Johnson ${ }^{3}$, E. Mougin ${ }^{22}$, \\ P. Hiernaux ${ }^{22}$, T. Killeen ${ }^{14,23}$, D. Metcalfe ${ }^{8}$, H. S. Miranda ${ }^{17}$, M. Steininger ${ }^{24}$, K. Sykora ${ }^{1}$, M. I. Bird ${ }^{2}$, J. Grace ${ }^{4}$, \\ S. Lewis ${ }^{3,26}$, O. L. Phillips ${ }^{3}$, and J. Lloyd ${ }^{16,27}$ \\ ${ }^{1}$ Centre for Ecosystem Studies, University of Wageningen, 6700 AA Wageningen, the Netherlands \\ ${ }^{2}$ School of Earth and Environmental Science, James Cook University, Cairns, Qld, Australia \\ ${ }^{3}$ Earth and Biosphere Institute, School of Geography, University of Leeds, England, UK \\ ${ }^{4}$ School of Geosciences, University of Edinburgh, Scotland, UK \\ ${ }^{5}$ Centre for Ecology \& Hydrology, Wallingford, England, UK \\ ${ }^{6}$ Instituto Nacional de Pesquisas da Amazonia, Manaus, Brazil \\ ${ }^{7}$ Forest Research Institute of Ghana, Kumasi, Ghana \\ ${ }^{8}$ CSIRO Ecosystem Sciences Tropical Forest Research Centre, Atherton, Qld, Australia \\ ${ }^{9}$ Australian Tropical Forest Research Institute, Cairns, Australia \\ ${ }^{10}$ Universidade do Estado de Mato Grosso, Nova Xavantina, MT, Brazil \\ ${ }^{11}$ Royal Botanic Garden, Edinburgh, Scotland, UK \\ ${ }^{12}$ Fundação Ecológica Cristalino, Alta Floresta, Brazil \\ ${ }^{13}$ Department of Biology, University of Yaoundé, Yaoundé, Cameroon \\ ${ }^{14}$ Museo Noel Kempff Mercado, Santa Cruz, Bolivia \\ ${ }^{15}$ Fieldwork Assistance, Jena, Germany \\ ${ }^{16}$ School of Marine and Tropical Biology, James Cook University, Cairns, Qld, Australia \\ ${ }^{17}$ Universidade de Brasilia, DF, Brazil \\ ${ }^{18}$ Resource Management Support Centre, Forestry Commission of Ghana, Kumasi, Ghana \\ ${ }^{19}$ Institut de l'Environnement et de Recherches Agricoles, Ouagadougou, Burkina Faso \\ ${ }^{20}$ Centre National des Semences Forestières, Ouagadougou, Burkina Faso \\ ${ }^{21}$ Ecole Normale Supérieure, Paris CEDEX 05, France \\ ${ }^{22}$ Géosciences Environnement Toulouse, Observatoire Midi-Pyrénées, Toulouse, France \\ ${ }^{23}$ World Wildlife Fund, Washington DC, USA \\ ${ }^{24}$ Conservation International, Washington DC, USA \\ ${ }^{25}$ Karlsruhe Institute of Technology, Institute of Meteorology and Climate Research, \\ Garmisch-Partenkirchen, Germany \\ ${ }^{26}$ Department of Geography, University College London, England, UK \\ ${ }^{27}$ Department of Life Sciences, Imperial College London, Silwood Park Campus, Buckhurst Road, \\ Ascot, Berkshire SL5 7PY, England, UK
}

Correspondence to: J. Lloyd (jonathan.lloyd@imperial.ac.uk)

Received: 12 December 2013 - Published in Biogeosciences Discuss.: 24 March 2014 
Revised: 13 April 2015 - Accepted: 21 April 2015 - Published: 21 May 2015

Abstract. Through interpretations of remote-sensing data and/or theoretical propositions, the idea that forest and savanna represent "alternative stable states" is gaining increasing acceptance. Filling an observational gap, we present detailed stratified floristic and structural analyses for forest and savanna stands located mostly within zones of transition (where both vegetation types occur in close proximity) in Africa, South America and Australia. Woody plant leaf area index variation was related to tree canopy cover in a similar way for both savanna and forest with substantial overlap between the two vegetation types. As total woody plant canopy cover increased, so did the relative contribution of middle and lower strata of woody vegetation. Herbaceous layer cover declined as woody cover increased. This pattern of understorey grasses and herbs progressively replaced by shrubs as the canopy closes over was found for both savanna and forests and on all continents. Thus, once subordinate woody canopy layers are taken into account, a less marked transition in woody plant cover across the savanna-forestspecies discontinuum is observed compared to that inferred when trees of a basal diameter $>0.1 \mathrm{~m}$ are considered in isolation. This is especially the case for shrub-dominated savannas and in taller savannas approaching canopy closure. An increased contribution of forest species to the total subordinate cover is also observed as savanna stand canopy closure occurs. Despite similarities in canopy-cover characteristics, woody vegetation in Africa and Australia attained greater heights and stored a greater amount of above-ground biomass than in South America. Up to three times as much aboveground biomass is stored in forests compared to savannas under equivalent climatic conditions. Savanna-forest transition zones were also found to typically occur at higher precipitation regimes for South America than for Africa. Nevertheless, consistent across all three continents coexistence was found to be confined to a well-defined edaphic-climate envelope with soil and climate the key determinants of the relative location of forest and savanna stands. Moreover, when considered in conjunction with the appropriate water availability metrics, it emerges that soil exchangeable cations exert considerable control on woody canopy-cover extent as measured in our pan-continental (forest + savanna) data set. Taken together these observations do not lend support to the notion of alternate stable states mediated through fire feedbacks as the prime force shaping the distribution of the two dominant vegetation types of the tropical lands.

\section{Introduction}

In general terms, "savannas" may be defined as woody vegetation formation types having a fractional grass/herb ground cover of at least 0.1 . They typically have a woody species composition quite distinct from "forests", the latter also typically (though not always) with no grasses and/or herbs present (Torello-Raventos et al., 2013). Together forest and savanna dominate the tropical vegetated regions covering 0.15 to 0.2 of the earth's surface (Walter and MuellerDombois, 1971).

At a broad scale it has long been recognised that the distributions of these two biomes are principally governed by precipitation and its seasonality (Schimper, 1903). Nevertheless, it is sometimes possible to find these different vegetation formation types growing in climatic zones where they do not usually occur. For example, stands dominated by species usually associated with forest vegetation formation types ("forest outliers") may be found at mean annual precipitations $\left(P_{\mathrm{A}}\right)$ of $<1.0 \mathrm{~m} \mathrm{a}^{-1}$ in both Australia (Fensham, 1995) and South America (Killeen et al., 2006). Conversely, savannas are often seen on sandy soils under precipitation regimes usually associated with forest $\left(P_{\mathrm{A}}>2.0 \mathrm{~m} \mathrm{a}^{-1}\right)$ with such "savanna inliers" having been reported for South America, Australia and Africa (Hopkins, 1992; Lloyd et al., 2008; TorelloRaventos et al., 2013).

There are also discrete regions where the two biomes intercept - often referred to as "ecotones" or "Zones of (Ecological) Tension" (ZOT) - where both forest and savanna exist as discrete "patches" under similar climatic conditions. Although the influence of soil structure in shaping vegetation distributions within such ZOT has long been recognised (Cochrane, 1989; Ratter, 1992; Thompson et al., 1992; Hoffmann et al., 2009; Lehmann et al., 2011; Saiz et al., 2012), the observation that the artificial exclusion of fire from savanna areas within ZOT is followed by invasion of forest species (Hopkins and Jenkin, 1962; Louppe et al. 1995; Swaine et al., 1992; Geiger et al., 2011) has led to the idea that forest and savanna stands may represent alternate stable states modulated by fire-mediated feedbacks (Warman and Moles, 2009; Hoffmann et al., 2012a; Murphy and Bowman, 2012). Here the regular recurrence of fire in savanna systems is considered to prevent these vegetation formations from becoming dominated by fire sensitive forest species. Instead the dominant species become grasses and savanna trees characterised by adaptations to a fire-prone environment (Gignoux et al., 2009; Hoffmann et al., 2012a; Murphy and Bowman, 2012).

The notion of fire-mediated bi-stability has gained increasing acceptance through analyses of a global tree canopycover data set (MOD44B; Hansen et al., 2002). A number of 
studies have interpreted the observation of a lack of canopy cover around 0.6 (fractional cover) in this data set to provide planetary-scale evidence of alternative states with forest considered to exist above this threshold (Hirota et al., 2011; Staver et al., 2011a, b; Murphy and Bowman, 2012). Firemediated feedbacks also form the basis of several models of tropical vegetation structure both across the ZOT and within savanna systems (Van Langevelde et al., 2003; Staver et al., 2011a; Higgins and Scheiter, 2012) with conceptual origins lying in theoretical frameworks of non-linear ecosystem population dynamics (May, 2001).

Hanan et al. (2013) have, however, recently pointed out that gaps in the distribution of the global vegetation-cover data set may be the result of statistical procedures of calibration rather than low frequency occurrences of crown-cover classes in the real world (though see also Staver and Hansen, 2015). Alternative explanations for the existence of observed tropical-cover distribution patterns such as plant water demand (Bertram and Dewar, 2013) and herbivory (Pachzelt et al., 2013) have also been used in modelling studies to explain woody-cover patterns not solely dependent on firemediated feedbacks.

Moreover, direct ground based empirical evidence for forest-savanna discontinuities and the existence of alternative stable states does not seem to have been actively sought. Nor has the structural and/or floristic (dis)similarity in composition of forests and savannas in ZOT been studied across continents in any sort of systematic manner. We do know, however, that fire-adapted woody species in vegetation types usually defined as "savannas", can attain forest-like woody canopy covers under certain circumstances (Torello Raventos et al., 2013).

In addition to climate, edaphic conditions may be particularly important in influencing tropical vegetation structure (Lloyd et al., 2009; Lehmann et al., 2011; Mills et al., 2013), with soil physical and/or chemical properties documented as being especially influential in ecotonal regions (Murdoch et al., 1976; Furley and Ratter, 1988; Cochrane, 1989; Ratter, 1992; Thompson et al., 1992; Saiz et al., 2012; Schrodt et al., 2014). But it is not necessary to regard fire-mediated vs. soil nutrient effects on savanna physiognomy as independent and mutually exclusive mechanisms. For example, Adejuwon and Adesina (1992) have argued that - although today's detailed forest-mosaic pattern in Nigeria is a relatively stable response to edaphic patterns - it has only become manifest through fire and cultivation pressures acting on the extensive forest which once existed there - see also Chapter 1 of Fairhead and Leach (1996) for more examples of this viewpoint. In a similar vein, Kellman (1984) has suggested that fire might naturally exert stronger effects on the structure and function of savanna vegetation formation types growing on less fertile soils: an argument recently restated by Hoffmann et al. (2012b) and, specifically for the Brazilian cerrado region by Franco et al. (2014).
In this paper we attempt to fill an obvious data gap by providing detailed ground-based observational information on vegetation structure changes across forest-savanna boundaries. An emphasis is placed on the evaluation of all layers of the canopy, particularly the lower shrub and grass/herb ("axylale") layers: these being particularly important in the categorisation of the different tropical vegetation formations (Torello-Raventos et al., 2013). Unlike most forest inventories, our detailed field-based data extend to woody vegetation layers below $5 \mathrm{~m}$ and trees with diameter $<0.1 \mathrm{~m}$ as these layers sometimes represent a substantial component of both forest and savanna total woody cover. Moreover, some savannas are even dominated by these shorter woody vegetation types (Eiten, 1972; Haase and Beck, 1989; Gentry, 1995; Killeen et al., 1998; Oberle et al., 2009; Torello-Raventos et al., 2013).

Indeed, changes in lower stratum woody plant density have already been noted as particularly important at the temperate zone "woodland/forest" transition (Laubenfels, 1975). Here it seems that as canopy closure occurs, competition for light becomes increasingly important and an "etiolation" of canopy structure ensues. This then creates a new low-light understorey environment dominated by specialist shade-adapted species. As a result of this new "niche creation" there is probably not much difference in the environmental conditions required to maintain a leaf area index $(L)$ of $>3$ vs. $L=1$. According to such a rationale, the typical smaller height of savanna trees as compared to their forest counterparts can be viewed as a simple consequence of not having to compete for light and with tree-height maxima then dictated only by considerations of individual tree canopy light interception and reproductive organ exposure taken in conjunction with stem and branch architectural and structural requirements (Gere, 2004; Sterk et al., 2006; van Gelder et al., 2006). This is in contrast to maximum tree height being constrained by hydraulic limitations as is usually assumed to be the case for well-watered forest ecosystems (Ryan and Yoder, 1997; Koch et al., 2004; Ryan et al., 2006); these being inevitably characterised by a high degree of above-ground competition for light and with vertical growth strategies emphasised accordingly (Falster and Westoby, 2003).

Aiming to explore the above issues, our analysis utilises a global data set of newly established sample plots - mostly located in ZOT - including specifically selected savanna inliers and forest outliers as well as low precipitation savanna formations, with a delineation of these into forest, woodland or savanna using a consistent set of rules designed to define tropical vegetation formation types globally (Torello Raventos et al., 2013). To our knowledge this analysis represents the first attempt to describe changes across ZOT using field data and at a global scale. As well as describing structural differences, we also provide first estimates of biomass differences for forest and savanna stands growing in close proximity in Australia, South America and Africa in anticipation that such data will be of considerable importance for global 
land use change carbon emission estimates (Malhi, 2010; Gloor et al., 2012; Houghton, 2012). Specific questions addressed include

1. Is there really a marked discontinuity in dominant strata canopy-cover distributions for tropical woody vegetation formation types as suggested by remote-sensing products? And if so, is this associated with an abrupt transition from (i) vegetation formation types characterised by an obvious grass/herb layer and dominated by fire-adapted woody species (savannas) to (ii) contrasting closed formations characterised by a very different woody species composition and with both grasses/herbs and fire virtually absent (forests)?

2. Does any such marked discontinuity in woody plant cover continue to exist once variations in all strata are taken into account? Specifically, around the point of upper-strata canopy closure, is there a replacement of grasses and/or herbs by shrubs and small trees not included in most ground-based plot inventories and most likely - also not detected by remote-sensing products?

3. Given that differing measures of woody plant abundance are used in tropical vegetation studies, to what extent do variations in canopy heights, canopy cover and stand-level biomass relate to each other across the savanna-forest transition? And what are the magnitude of these variations? In particular, might it be, that when climate and soils combine to provide conditions sufficient for canopy closure, rapid increases in both canopy height and stand-level biomass occur as a consequence of increased competition for light? As opposed to variations in tree heights along precipitation gradients being controlled by differences in water availability.

4. Given the likely influence of soils as key modulators of tropical vegetation structure, to what extent might edaphic factors provide an explanation for savanna and forest sometimes being found under apparently identical climate conditions? And if the soil effect is significant, is an invocation of "alternative stable states" then necessary for an understanding of the otherwise enigmatic distribution patterns of forest and savanna vegetation formation types across the tropical lands.

\section{Materials and methods}

With an objective of quantifying what factors define changes in vegetation structure and physiognomy across savannaforest boundaries in so-called ZOT, measurements of forest and savanna vegetation structure were made in ZOT located in Australia, Africa and South America. Sites had been selected with a view to maximising differences in climate and soils to allow an analysis of global applicability. The criteria of plot selection and establishment are detailed in TorelloRaventos et al. (2013). Drier savanna and forest plots were also examined in Australia, Bolivia and West Africa and with higher precipitation forest and savanna sites also studied in Brazil and Australia. A map showing all plot locations is given in Fig. 2 of Torello-Raventos et al. (2013) with a list of all plots studied: their location, vegetation formation type, basic climatology and soil type also being provided here (see Table S1). Nomenclature of the various vegetation types follows Torello-Raventos et al. (2013) and in what follows all that is not referred to as some form of "forest" is, by definition, considered part of the "savanna domain". This includes all "grassland", "savanna" and "woodland" types. A list of symbols used is given in the main text Appendix.

In terms of natural and human-mediated disturbances, some sites were fire-protected and with domestic animal grazing specifically excluded, but for others, especially in West Africa, farm animals were observed grazing in or near the sample plots. For all plots, there were no barriers placed to the grazing of vegetation by the natural fauna. Table A1 of Torello-Raventos et al. (2013) gives details of plot histories (in terms of those previously or newly established), plot protection status and perceived anthropogenic influences (grazing and fire protection or promotion).

\subsection{Study sites}

Measurements were made from July 2006 to March 2009 in five field campaigns, each over a period of ca. 2 months with as many plots as possible sampled within the allocated time and summarised as follows: West Africa (Ghana, Burkina Faso and Mali: 14 plots; August to October 2006), Bolivia (11 plots; February to May 2007) Cameroon (8 plots; November to December 2007), Brazil (17 plots; April to June 2008) and Australia (11 plots; February to April 2009). All sampling campaigns were timed to coincide with the end of the wet season and associated expected maximum plant physiological activity and standing herbaceous biomass.

\subsection{Tree and shrub canopy area index}

Defining a canopy area index $(C)$ as the sum of individual tree canopy projected area (including the skylight transmitted component) divided by the ground area as detailed in Torello-Raventos et al. (2013), $C$ was estimated separately for three woody strata within each plot, viz. for the upper (subscript "U"), mid-stratum (subscript "M"), and subordinate (subscript "S") layers: the different strata are distinguished on the basis of stem diameter at breast height $(1.3 \mathrm{~m})$ $D$, and individual tree height $(H)$. Data used here are as presented in Torello-Raventos et al. (2013), with precise definitions of $C_{\mathrm{U}}, C_{\mathrm{M}}$ and $C_{\mathrm{S}}$ given in their Table 1 . In short, the upper stratum was considered to consist of all woody elements $D>0.1 \mathrm{~m}$; the middle stratum all woody elements with $H>1.5 \mathrm{~m}$ and $25 \mathrm{~mm}<D<0.1 \mathrm{~m}$ and the lower stra- 
tum all other woody plant present (viz. less than $1.5 \mathrm{~m}$ high and/or $D<25 \mathrm{~mm}$ ).

For some analyses presented here the woody canopy-cover component was also divided into trees and shrubs, these being segregated as in Torello-Raventos et al. (2013). In brief, shrubs are defined as woody species with either a single stem (bole) of length at least $1.5 \mathrm{~m}$, but with height less than $3 \mathrm{~m}$, or a woody species with a stem length prior to branching of less than $1.5 \mathrm{~m}$ (also being less than $5 \mathrm{~m}$ height). The associated tree and shrub canopy area indices are designated as $C_{\mathrm{t}}$ and $C_{\text {Sh }}$ respectively and are as formally defined in Table 1 of Torello-Raventos et al. (2013).

Also considered separately here is a division of the woody vegetation according to height, with the total woody plant canopy cover (all trees and shrubs taller than $1.5 \mathrm{~m}$; woody plant canopy area index $-C_{\mathrm{W}}$ ) and seedling canopy cover (all trees and shrubs less than $1.5 \mathrm{~m}$ tall; $C_{\mathrm{Se}}$ ), again as defined in Table 1 of Torello-Raventos et al. (2013).

\subsection{Fractional canopy covers}

Assuming a random distribution of trees and/or shrubs, the crown cover, viz. the fraction of ground covered by crowns (including within-crown light gaps) referred to here as the fractional crown cover $(\varsigma)$, can be estimated for any combination of layers $(Z)$ as

$\varsigma Z=1-\exp \left(-\sum_{i=1}^{n} C_{i}\right)$

where $n$ is the number of layers. For example, for the uppertwo layers then $n=2$ and

$\varsigma \mathrm{W}=1-\exp \left(-C_{\mathrm{U}}-C_{\mathrm{M}}\right)$

Likewise for a single layer or vegetation form (e.g. shrubs) then

$\varsigma_{\mathrm{Sh}}=1-\exp \left(-C_{\mathrm{Sh}}\right)$

Savanna vegetation may, however, be clumped and so we tested for complete spatial randomness (CSR) using a $G$ function (Bivand et al., 2008) via the R spatstat package (Baddeley and Turner, 2005). The $G$ function measures the distribution of distances from an arbitrary event to its nearest neighbour and comparisons of the theoretical expectation for CSR against that actually observed. There were only minor indications of clumping for the plots tested suggesting little if any underestimation of fractional covers using Eq. (1; see Sect. S2 in the Supplement).

Estimates of various $\varsigma$ are used extensively throughout this paper (and always with subscripts as above) and here we note that estimates of $\varsigma$ are not numerically or conceptually the same as those often presented for (fractional) woody canopy cover which - in remote-sensing studies - is defined as "the portion of the skylight orthogonal to the surface which is intercepted by trees" (e.g. Hansen et al., 2002). Defining then $\alpha$ as the average proportion of skylight passing through each tree, and noting that canopy cover as defined above is essentially equivalent to the fractional foliage cover or projective foliar cover of the stratum in question, $\zeta$ (Lloyd et al., 2008), it then follows that $\zeta=\alpha \zeta$.

Estimates of the fractional canopy cover of grasses, herbs and other non-woody life forms in the ground layer (referred to from here on as "axylales") are as in Torello-Raventos et al. (2013). Here we use the term "axylale", originally coined by Du Rietz (1936), as a concise yet all-encompassing term for plants with non-lignified stems: this definition thus incorporating all grass-, herb-, sedge- and forb-type life forms into the one category without any necessary reference to taxonomic grouping (Ingrouille and Eddie, 2006). Axylale fractional cover $\left(\zeta_{\mathrm{a}}\right)$ was visually recorded along a series of transects with a typical sampling intensity of $110 \times 1.0 \mathrm{~m}^{2}$ quadrants per 1 ha plot.

\subsection{Canopy height}

The upper-stratum $H$ was estimated as described in Feldpausch et al. (2011) and Torello-Raventos et al. (2013). In short, site-specific allometric equations were developed to calculate 0.95 quantile and average woody plant heights for the upper stratum $(D \geq 0.10 \mathrm{~m})$, these being denoted as $H^{*}$ and $\langle H\rangle_{\mathrm{U}}$, respectively.

\subsection{Stand-level leaf area index}

Leaf area index of trees and shrubs taller than $1.5 \mathrm{~m}(L)$ was assessed using hemispherical photography. True-colour images were taken under diffuse light conditions (mostly sunrise and sunset) with a Nikon Coolpix 8800VR camera and Nikon Fisheye Lens FC-E9 set at aperture 8.0 with a twostep underexposure (Zhang et al., 2005). At most sites 10 to 25 images were taken at the centre of $25 \mathrm{~m} \times 25 \mathrm{~m}$ grid cells but for a few sites with very sparse woody cover, hemispheric images were taken from randomly selected trees. This is because of a potentially problematic determination of $L$ from grid hemispherical images in open vegetation $(L \leq 1.5)$ as detailed by Ryu et al. (2010).

Images were analysed with the Gap Light Analyser software Version 2 (Frazer et al., 1999) and in applying the technique two or more observers independently determined image-specific threshold and contrast settings to reduce observer error. For each image, $L$ was calculated from an integration over the zenith angles $0-75^{\circ}$ after trunk and/or branch elements had been removed through manual editing. If images contained individual trees with non-overlapping crowns, fraction canopy cover in the image was also measured for each image by blackening total canopy area and determining canopy openness. Canopy-level $L$ was then determined by dividing image $L$ by image canopy fraction. For plots, where only images of individual trees were taken, $L$ was determined by multiplying the average individual tree 
estimates of $L$ by the $C_{\mathrm{W}}$. Comparison of results of this calculation with $L$ determined from grid cell images (if sites had images with non-overlapping crowns) gave comparable results particularly if $L<1.0$.

Estimates for end of season $L$ for the axylale layer were determined from clipping standing biomass (by drying to constant weight) in 5 to 10 randomly selected $1.0 \mathrm{~m}^{2}$ plots. Leaf area of these samples was determined by scanning the fresh surface of a subsample of the clipping before determination of specific leaf area.

\subsection{Shrub and seedling-dominance indices}

To quantify the relative dominance of shrubs in the ground layer relative to herbs and grasses (axylales), we defined a "shrub-dominance index" $\left(\chi_{1}\right)$ as

$\chi_{1}=\frac{\varsigma_{\mathrm{Sh}}-\zeta_{\mathrm{a}}}{\varsigma_{\mathrm{Sh}}+\zeta_{\mathrm{a}}}$

where (as defined above) $\varsigma_{S h}$ is the shrub crown projected cover and $\zeta_{\mathrm{a}}$ is the axylale fractional cover. A second metric which quantifies competition between herbaceous and woody elements of the subordinate layer, a "seedlingdominance index", $\chi_{2}$, was also defined, viz.

$\chi_{2}=\frac{\zeta \mathrm{Se}-\zeta_{\mathrm{a}}}{\varsigma \mathrm{Se}_{\mathrm{Se}}+\zeta_{\mathrm{a}}}$

where $\zeta_{\mathrm{Se}}$ is the crown projected cover of all tree and shrub seedlings (as defined above). The two indices (which can both potentially vary from -1 to +1 ) differ in that $\chi_{1}$ quantified the relative dominance of shrubs over axylales in the understorey (but ignoring any tree seedlings or tree saplings), whereas $\chi_{2}$ provides a measure of the relative abundance of both tree and shrub seedlings relative to herbaceous-cover extent.

\subsection{Tree, shrub and liana biomass}

\subsubsection{Forests}

For all forest plots sensu lato Torello-Raventos et al. (2013), we applied a global equation for predicting above-ground biomass $(B)$ from diameter at breast height $(D), H$ and density $(\rho)$ using the "dry forest" equation of Chave et al. (2005) for all trees of $D \geq 25 \mathrm{~mm}$ (see Eq. (S1) in Table S2). Wood density values were obtained from Zanne et al. (2009) for Africa and South America and Ilic et al. (2000) for Australia. Unknown species densities were calculated using the mean values of the closest taxon. For forest shrubs we developed our own generic equations for predicting $B$ from basal area $\left(A_{\mathrm{B}}\right)$ or crown diameter $\left(D_{\mathrm{C}}\right)$ these being based on destructive measurements of 63 randomly selected individuals of the species Acacia tenuifolia, Croton argyroglossus, Tetrapterys racemulosa and two unidentified Acacia species harvested at the Tucavaca stunted forest and shrub-rich woodland site in
Bolivia (TUC-01 and TUC-02). The resulting parameterisation (see Eqs. (S2) and (S3) in Table S2) gave rise to predictions similar to another equation derived independently for Indian understorey forest shrubs (Singh and Singh, 1991) suggesting a general applicability. For lianas we applied an equation from Schnitzer et al. (2006) and for palms the equation of de Castilho et al. (2006) - both these parameterisations predicting $B$ from $D$ (see Eqs. (S4) and (S5) in Table S2 in the Supplement).

\subsubsection{Savannas}

For taller savanna trees in the African humid savannas of Burkina Faso, Cameroon and Ghana $(H>10 \mathrm{~m})$, we applied a generic allometric relationship for predicting $B$ from $D$ and $H$, originally developed for miombo woodland trees (Malimbwi et al., 1994). This parameterisation (see Eq. (S6) in Table S2), tested for African savanna trees using unpublished data from the Ivory Coast (Menaut, 1971), was confirmed as a good predictor for large trees $(H>10 \mathrm{~m})$, but with a tendency to underestimate $B$ for medium to smaller sized trees. For the more humid West African and Cameroon savanna plots, we therefore developed new equations for all trees of $D>25 \mathrm{~mm}$ and $H<10 \mathrm{~m}$ using the Menaut (1971) data set (see Eqs. (S7) and (S8) in Table S2). For trees in the Sahelian savanna plots (HOM-01 and HOM-02), we used a parameterisation from Henry et al. (2011) using $D$ as the predictor variable (see Eq. (S13) in Table S2) with the biomass parameterisations for trees in the Guinean savannas BDA01 and BDA-02 (Alexandre and Kairé, 2001) also as given in Henry et al. (2011) with $B$ derived from basal area $\left(A_{\mathrm{B}}\right)$ measurements (see Eq. (S14) in Table S2). For shrubs at these drier sites, we used an equation from Skarpe (1990) with $B$ estimated from crown area $\left(A_{\mathrm{C}}\right)$ measurements (see Eq. (S10) in Table S2). For the subligneous fire resprouter shrub Cochlospermum planchonii (dominant in the Burkina Faso plots DAN-01 and DAN-02), a separate equation was developed (see Eq. (S9) in Table S2) with $B$ calibrated against $A_{\mathrm{C}}$. For shrubs and trees in South American cerrados, we used an equation taken from Ribeiro et al. (2011) with $B$ derived from $D, H$ and $\rho$ (see Eq. (S11) in Table S2). Biomass of Australian trees and shrubs with $D>25 \mathrm{~mm}$ was estimated following Williams et al. (2005) with $B$ derived from $D$ and $H$ (see Eq. S12).

\subsection{Climate}

As in Torello-Raventos et al. (2013), we estimated an index of plant water supply in relation to evaporative demand $W$, calculated as (Berry and Roderick, 2002)

$W=P_{\mathrm{A}}-Q_{\mathrm{s}} /(\rho \lambda)$,

where $P_{\mathrm{A}}$ is mean annual precipitation rate, $Q_{\mathrm{s}}$ is mean annual global solar radiation, $\rho$ is the density of liquid water and $\lambda$ is the latent heat of evaporation for water. Temper- 
ature and precipitation climatologies for all sites were obtained from the interpolated WorldClim data set (see http: //www.worldclim.org/) with mean annual solar radiation data obtained from NASA's Langley Atmospheric Sciences Data Center Distributed Active Center (DAAC) assimilated from daily records (1983 to 2005).

\subsection{Soil cation status}

Soil sampling and exchangeable cation determination methods are as described in detail in Quesada et al. (2010) and (2011) and are thus only briefly summarised here. In short, exchangeable aluminium, calcium, magnesium, potassium and sodium, viz. $[\mathrm{Al}]_{\mathrm{E}},[\mathrm{Ca}]_{\mathrm{E}},[\mathrm{Mg}]_{\mathrm{E}},[\mathrm{K}]_{\mathrm{E}}$ and $[\mathrm{Na}]_{\mathrm{E}}$, were determined by the silver-thiourea method (Pleysier and Juo, 1980) with a simple measure of soil fertility defined here being the "total major nutrient cations", $N^{+}$:

$N^{+}=[\mathrm{Ca}]_{\mathrm{E}}+[\mathrm{Mg}]_{\mathrm{E}}+[\mathrm{K}]_{\mathrm{E}}$

with all cation concentrations expressed as $\mathrm{meq}^{+} \mathrm{kg}^{-1}$ and integrated across the top $0.3 \mathrm{~m}$ of soil depth.

\subsection{Plant available water}

Particle size analysis was performed using the pipette method (Gee and Bauder, 1986) with plant available soil water $\theta_{\mathrm{P}}$ obtained through an estimation of soil water retention characteristics based on the particle size pedotransfer functions for tropical soils given by Hodnett and Tomasella (2002) for each sampled layer. Individual layer estimates $(-0.01$ to $-1.5 \mathrm{MPa}$ ) were then integrated to the maximum rooting depth for each profile or integrated to $4 \mathrm{~m}$ for the case of roots not observed to be constrained in any way.

\subsection{Statistical analysis}

All analyses used the R statistical platform (R Development Core Team, 2012). Mixed effects and/or generalised additive models (Figs. 1 and 3) were developed using the mgcv and/or nlme packages (Wood, 2006; Pinheiro et al., 2015) allowing for heterogeneity in variances considered in model fits using varClasses functions. Breakpoint regression analyses (Fig. 4) were with the segmented package (Muggeo, 2008); robust (rank-based) linear regression analyses (Figs. 5-8) used the high breakpoint (HBR) option of wwest (Terpstra and McKean, 2005) and standard major axis regression (Fig. 10) was undertaken using smatr (Warton et al., 2012).

To assess the relationship between $C_{\mathrm{W}}$ and various soil and environmental variables (Fig. 11), we used Kendall's $\tau$ as a non-parametric measure of association. Compared to Spearman's $\rho$, Kendall's $\tau$ has slightly better distributional properties and can be interpreted in terms of probabilities of observing concordant and discordant pairs (Conover, 1980). Kendall's $\tau$ also has the advantage that it can be generalised

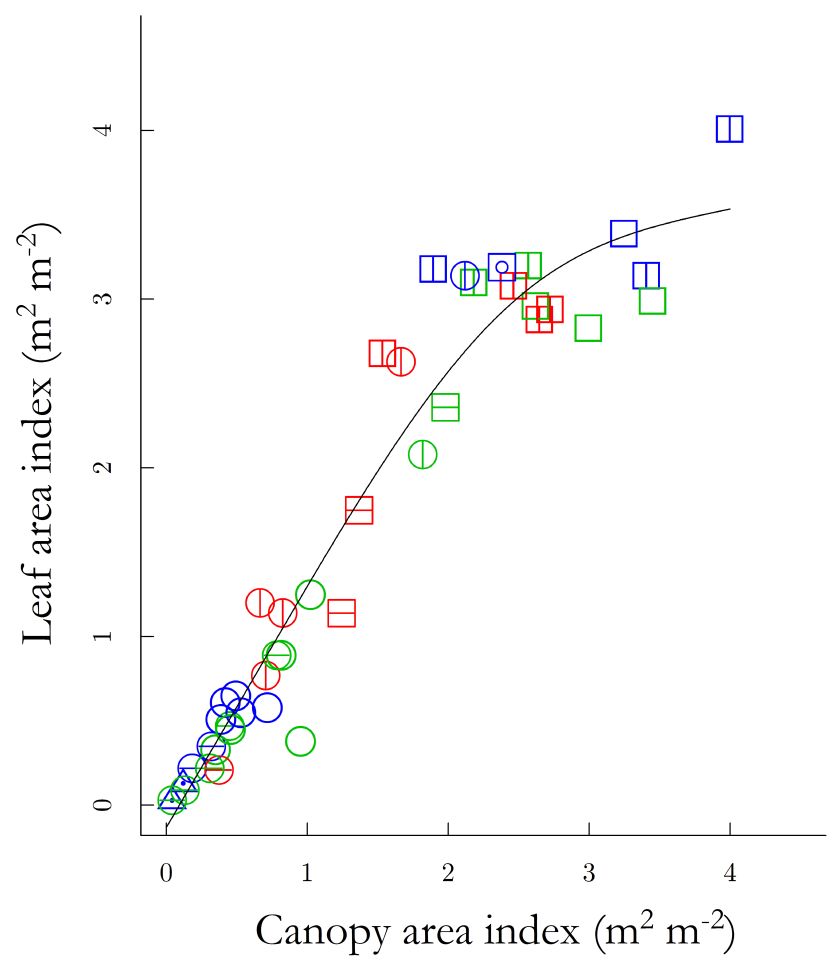

Figure 1. Relationship between woody plant canopy area index $\left(C_{\mathrm{W}}\right)$ and leaf area index $(L)$ symbols, $(\triangle)$ grassland and grassland savanna, $(\ominus)$ shrub-rich savanna formation types, $(\bigcirc)$ savanna and woodland formation types, $(\oplus)$ tall woodlands, $(\boxminus)$ stunted forests, $(\square)$ forest, $(\square)$ tall forest. Vegetation nomenclature follows Torello-Raventos et al. (2013). Blue symbols, Africa; Green symbols, South America; Red symbols, Australia. The fitted line represents a quadratically penalised generalised general linear model fit with the variance modelled as an exponential function of $C_{\mathrm{W}}$.

to a partial correlation coefficient (Legendre and Legendre, 2012; pp. 212). We assessed likely significance levels of our calculated partial $\tau$ by numerical simulation as described in Maghsoodloo and Laszlo Pallos (1981).

\section{Results}

\subsection{Leaf vs. canopy area index}

The relationship between woody vegetation estimates from hemispherical photographs $(L)$ and $C_{\mathrm{W}}$ values obtained from ground-based inventories is shown in Fig. 1. Here, as in most subsequent diagrams, sites have first been grouped into vegetation domain, viz. savanna and forest. Both vegetation formation types are further categorised into three structural groups and with continents identified by colour. For the forests, the prefix "stunted" applies to those forests with a mean canopy height (upper stratum) of less than $12 \mathrm{~m}$ and "tall forests" have an upper stratum 0.95 quantile height of more than $36 \mathrm{~m}$. For the savanna domain, "shrub savan- 
nas" have a mean canopy height of less than $6 \mathrm{~m}$ (also with a canopy area index between 0.3 and 0.7 ) with "tall savannas" having a mean upper-stratum canopy height greater than $12 \mathrm{~m}$.

Figure 1 suggests a uniform but non-linear relationship across vegetation types and continents, tending towards an asymptote at $C_{\mathrm{W}} \simeq 2$ (at which $L \simeq 2.7$ ). Below this point the ratio $L / C_{\mathrm{W}}$ is reasonably invariant indicating a reasonably constant leaf area density (leaf area per unit projected canopy area; $\ell_{\mathrm{D}}$ ) of around 1.25 , declining to less than 1.0 at high $L$. Thus, under conditions permitting only limited foliage development variations in $L$ are a direct consequence of variations in $C_{\mathrm{W}}$ (with a more or less constant $\ell_{\mathrm{D}}$ ). But at higher $C_{\mathrm{W}}$ there is a compensatory reduction in $\ell_{\mathrm{D}}$. Most importantly, Fig. 1 shows that, although the relationship between $L$ and $C_{\mathrm{W}}$ is non-linear, $C_{\mathrm{W}}$ provides a reasonable proxy for stand-level $L$ that is broadly consistent across both vegetation type and continent.

\subsection{Variations in canopy structure}

Patterns of variation in $C_{\mathrm{W}}$, mean upper-stratum canopy height, $\langle H\rangle_{\mathrm{U}}$, and 0.95 quantile upper-stratum canopy height, $H^{*}$ in relation to $W$ are presented in Fig. 2. Overall, similar patterns of variation were observed for all three stand properties with a large increase in crown covers and tree heights around $W=-1.3 \mathrm{~m} \mathrm{a}^{-1}$, which also corresponded to the typical ZOT location. Here we also note that although we observed the expected strong pattern of savannas being found at $W \leq-1.3 \mathrm{~m}$, and vice versa for forests, there were clear exceptions to the general case with stunted forest stands (as defined on the basis of structure and floristics; Torello-Raventos et al., 2013) in both Australia and South America having been sampled at $W \leq-1.8 \mathrm{~m} \mathrm{a}^{-1}$ and likewise with savanna being found on these two continents at $W-1.0 \mathrm{ma}^{-1}$. Generally speaking, when found at low $W$ the sampled forest "outlier" stands although not taller than their savanna counterparts (Fig. 2b and c), did have a greater $C_{\mathrm{W}}$ (Fig. 2a), but with the high $W$ savanna "inliers" both being shorter and with a lower $C_{\mathrm{W}}$. Also of note - excluding the driest two points (of less than $-2.4 \mathrm{~m} \mathrm{a}^{-1}$ located less than $100 \mathrm{~km}$ south of the Sahara Desert) - is a lack of any clear relationship between $W$ and any of our three stand-levels for both $W \leq-1.4 \mathrm{~m} \mathrm{a}^{-1}$ (mostly savanna) and $W \geq-1.0 \mathrm{~m} \mathrm{a}^{-1}$ (mostly forest); and with the $W$ of rapid transition being at a noticeably lower $W$ for Africa/Australia than for South America.

Although Fig. 2 does provide some useful information on changes in canopy structure in relation to climate, the range in $W$ over which the bulk of the changes occur is quite narrow. So in Fig. 3 we examine changes in the fractional cover of the individually measured woody components and axylale layer (see Sect. 2.2. and 2.3) as a function of $C_{\mathrm{W}}$. Here, with the exception of the axylale layer in Fig. 3f, these plots should be regarded as a simple investigation as to how the various different contributions made to $C_{\mathrm{W}}$ vary with $C_{\mathrm{W}}$ itself. But with the individual components expressed as fractional covers rather than as $C_{\mathrm{WU}}, C_{\mathrm{M}}$, etc. This is to enable direct comparison of results with earth observation products (Sect. 2.3)

Increases in $\varsigma$ as $C_{\mathrm{W}}$ increases are shown for the $U, M$ and $S$ woody strata in Fig. 3a-c (left side panels). Consistent with it being the dominant strata, $\varsigma \mathrm{U}$ shows a tendency toward saturation beyond $C_{\mathrm{W}} \simeq 2$, with both $\varsigma_{\mathrm{M}}$ and $\varsigma_{\mathrm{s}}$ accounting for most of the increase in $C_{\mathrm{W}}$ beyond that. Differences between continents are limited and, although overlap is limited, there is little to suggest any systematic difference between forest and savanna. Figure 3a also shows an apparent gap in the data around $0.55 \leq \varsigma \mathrm{U} \leq 0.65$ for the upper stratum, but with both forest and savanna stands occurring above and below this break at around $C_{\mathrm{W}} \simeq 1.5$. By contrast, no similar discontinuity is observed for either $\varsigma_{\mathrm{M}}$ or $\varsigma_{\mathrm{S}}$.

The same data are shown in Fig. $3 \mathrm{~d}$ and e, but in this case divided into trees (t) and shrubs (Sh). As $C_{\mathrm{W}}$ increases $\varsigma_{\mathrm{t}}$ shows a saturating function similar to $\varsigma_{U}$ though with much less variability (though with two Australian forests occurring at unusually low rainfalls as clear outliers). The shrub fractional cover is clearly more variable than for trees (Fig. 3e). At least in part this can be attributed to the presence of shrub-dominated savannas at some of the lowest $C_{\mathrm{W}}$ (these occurring on all three continents and for clarity enclosed by the dotted-line polygon in Fig. 3e) and the modelled line shown has been parameterised excluding these shrubdominated sites so as to give an indication of how $\varsigma_{U}$ varies with $C_{\mathrm{W}}$ just for those savanna and forest formations with a distinct upper-stratum dominated by trees. This suggests a rapid increase in $\varsigma_{\mathrm{Sh}}$ at $C_{\mathrm{W}} \simeq 1$, peaking around $C_{\mathrm{W}}=1.5$ and maintained around $\varsigma_{\mathrm{Sh}}$ at higher $C_{\mathrm{W}}$, at least for the forests within the ZOT as examined here. This increase in $\varsigma_{\mathrm{Sh}}$ at $C_{\mathrm{W}} \simeq 1$ is observed first in tree-dominated savannas and stunted forests and it is only at $C_{\mathrm{W}} \geq 2$ where the data are dominated by forest sites that $\zeta_{\mathrm{Sh}}$ tends to level out at a value of about 0.2 .

Figure $3 \mathrm{f}$ shows axylale fractional cover $\left(\zeta_{\mathrm{a}}\right)$ to decline with increasing $C_{\mathrm{W}}$, first reaching a minimum at $C_{\mathrm{W}} \simeq 2$ for both forest and savanna formation types. There is a reasonably strong relationship between $\zeta_{\mathrm{a}}$ and axylale leaf area index (see Fig. S6) and therefore, taken in conjunction with Fig. 3e, it can be concluded that as canopy closure occurs beyond $C_{\mathrm{W}} \simeq 1$ the herbaceous layer (generally dominated by $\mathrm{C}_{4}$ grasses in these ecosystems) declines being replaced by an increasingly dominant shrub layer. Importantly, this change in dominance is not associated with a transition from savanna to forest, but is rather first observed in the woodier savanna formation types.

The consequences of any attempt to define tropical vegetation formations solely on the basis of changes in upperstratum cover can be seen in Fig. 4 where the estimated stand-level crown cover is plotted against that of the upper stratum only. Here the shaded area between the fitted seg- 

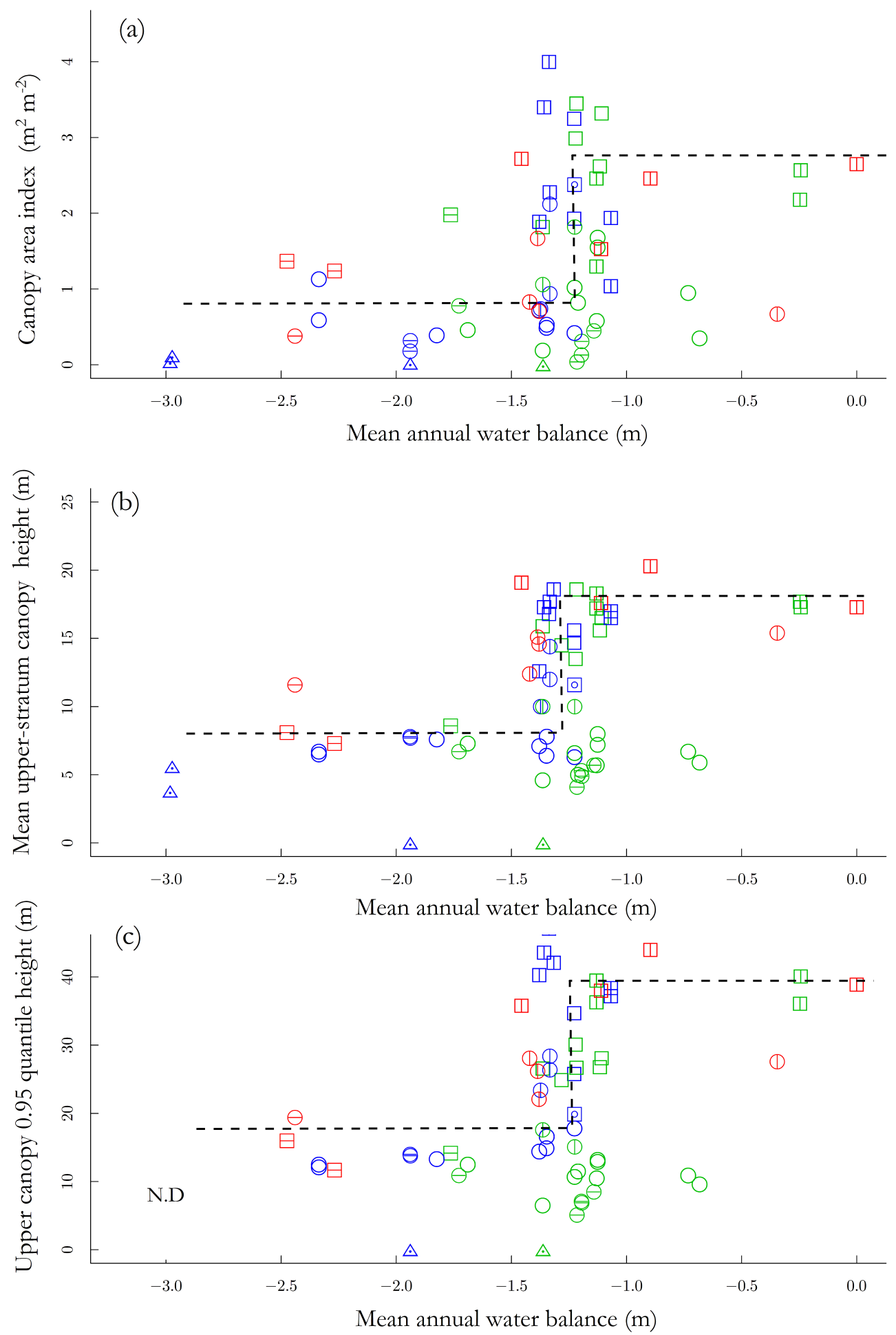

Figure 2. Relationship between estimated mean annual water balance and (a) total woody plant canopy area index; (b) mean upper-stratum canopy height and (c) upper stratum 0.95 quantile height. Symbols as in Fig. 1 with lines fitted by eye. 

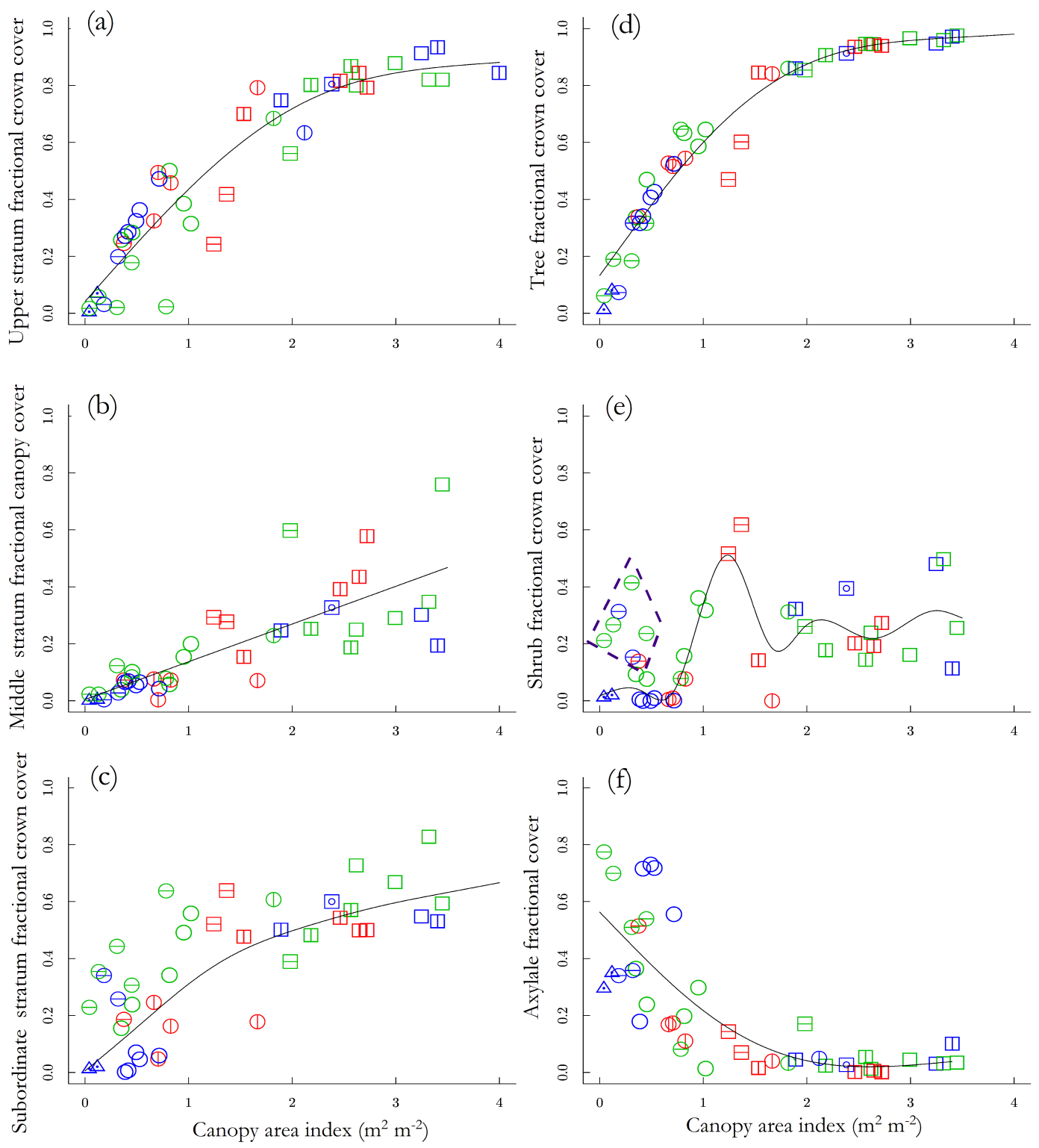

Figure 3. Relationship between various measures of canopy structure and woody plant canopy area index. The three left hand side panels are separated by the woody vegetation forms according to stratum, viz. upper, middle and subordinate; the three right hand panels are separated according to physiognomic form, viz. trees, shrubs and axylales (i.e. herbs and grasses). (a) Upper stratum is ,all trees with $D>0.1 \mathrm{~m}$; (b) middle stratum is all trees and shrubs $(25 \mathrm{~mm}<D<0.1 \mathrm{~m}$ and $H>1.5 \mathrm{~m})$; (c) subordinate stratum is ,all tree and shrub species $(H>1.5 \mathrm{~m})$; (d) all tree species (including seedlings); (e) all shrub species (including seedlings) and (f) non-woody plants (axylales). Symbols as in Fig. 1. The fitted lines represent a quadratically penalised generalised general linear model fit which for (d) and (e) excludes the shrubby savannas (enclosed in the dotted-lined polygon in (e); see also text). 


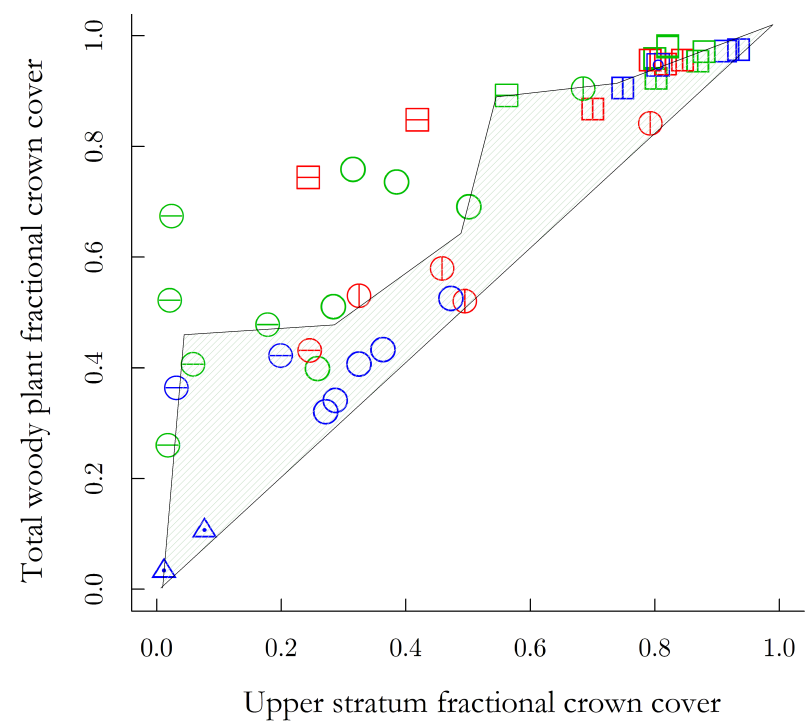

Figure 4. Fractional cover of all woody layers combined (including seedlings) vs. the fractional cover of the upper stratum only $\left(\zeta_{U}\right.$; all trees with $D>0.1 \mathrm{~m}$ ). The upper (disjointed) line represents the result from a segmented regression fit to the data $\left(r^{2}=0.84\right)$ with the bottom line representing the $1: 1$ relationship. The hatched area therefore shows the average difference between the two estimates for which the area is greatest at $\zeta_{\mathrm{U}} \lesssim 0.25$ and $0.55 \lesssim \zeta_{\mathrm{U}} \lesssim 0.80$. Symbols as in Fig. 1.

mented regression line (Muggeo, 2008) and the 1:1 relationship shows the average woody cover overlooked by an "upper-stratum-only" approach. Differences are the greatest for $\varsigma_{U} \leq 0.2$ and $0.5 \leq \varsigma_{U} \leq 0.7$ : these ranges associated in the first instance with the presence of shrub-dominated savannas and in the second instance with the higher relative dominance of shrub cover for vegetation characterised by $1 \geq C_{\mathrm{W}} \geq 2$.

\subsection{Shrub and seedling dominance}

Differences in the relative dominance of shrubs within the understorey in relation to axylale cover as affected by the upper-canopy cover is illustrated through a plotting of the shrub-dominance index $\left(\chi_{1}:\right.$ Eq. $\left.2 a\right)$ as a function of $\varsigma_{U}$ in Fig. 5a. This shows $\chi_{1}$ to increase with increasing $\varsigma_{U}$, both as savanna tree density increases and across the savanna-forest transition. There are, however, distinct outliers as detected by the robust regression fitting technique, these being (longgrassed) savanna woodlands in Africa and tall savanna woodlands in Australia. When the $\chi_{2}$ is applied (i.e. including tree seedlings, but excluding any shrubs taller than $1.5 \mathrm{~m}$ ) then most of the Australian tall savanna woodlands fall into line (Fig. 5b), but with the long-grassed African savanna woodlands still identified as clear outliers. Thus, although there are exceptions, there is a clear tendency for grasses and herbs to be replaced by seedlings and shrubs in the lower strata as canopy closure occurs higher up. This is seen first in wood- ier savannas (beyond $\varsigma \mathrm{U} \simeq 0.3$ ) extending then to the higher leaf area forest vegetation formation types.

\subsection{Species composition of understorey}

The presence of forest and savanna species in the middle and subordinate layers of savanna vegetation formation type plots is examined as a function of total fractional cover (this consisting mainly, though not exclusively, of savanna tree species) in Fig. 6a. This shows that beyond $\varsigma_{U} \simeq 0.4$ there is a marked increase in the abundance of forest species associated with the upper-canopy closure within savanna vegetation formation types. On the other hand, there is no relationship between $\varsigma \mathrm{U}$ and the cover of subordinate savanna tree and shrub species for these same stands (Fig. 6b).

\subsection{Crown-cover-height allometry}

Upper-stratum quantile height $\left(H^{*}\right)$ is examined as a function of the associated upper-canopy crown cover $\left(\varsigma_{U}\right)$ in Fig. 7. This illustrates, for the South American savannas in particular, that there is relatively little variation in $H^{*}$ across a wide range of intermediate $\varsigma_{U}$. At any given $\varsigma_{U}$ it can be seen that $H^{*}$ is lower for South American savanna and/or forest than for Africa or Australia. There is however an increase in $H^{*}$ associated around the point of canopy closure $(\varsigma \mathrm{U} \simeq 0.7)$ with the transition from savanna to forest in South America more gradual than in the other continents, especially once the stunted forests found at unusually low $W$ (Fig. 2) are taken into account.

\subsection{Biomass-height allometry}

The relationship between crown cover and biomass of the upper stratum ( $\left.B_{\mathrm{U}}: D \geq 0.1 \mathrm{~m}\right)$ - this being the only layer usually studied for estimates of forest biomass (e.g. Feldpausch et al., 2012) - is shown in Fig. 8a. Here we find a strong reciprocal relationship and, although there is a rapid increase in $B_{\mathrm{U}}$ for $\varsigma_{\mathrm{U}}>0.8$ (including a few savanna plots), there is also considerable variation in $B_{\mathrm{U}}$ beyond this point with differences of over $300 \mathrm{t} \mathrm{ha}^{-1}$ possible at any given $\varsigma_{U}>0.8$. A generally more consistent relationship is observed when biomass and crown canopy cover are examined at the whole stand level (Fig. 8b) and with some overlap between savanna and forest observed in both cases. The higher biomass of the tall savanna types is also clearly demonstrated by this diagram which also shows that, even at a $\varsigma \mathrm{U}$ of only 0.5 , some Australian tall savanna formations can have a biomass approaching that of much higher crown cover South American and African forest formations.

\subsection{Forest-savanna biomass differences}

Figure 9 shows the biomass of all forest and savanna plots (excluding seedlings) as a function of the mean annual water availability, $W$, as calculated in Eq. (3). For each con- 

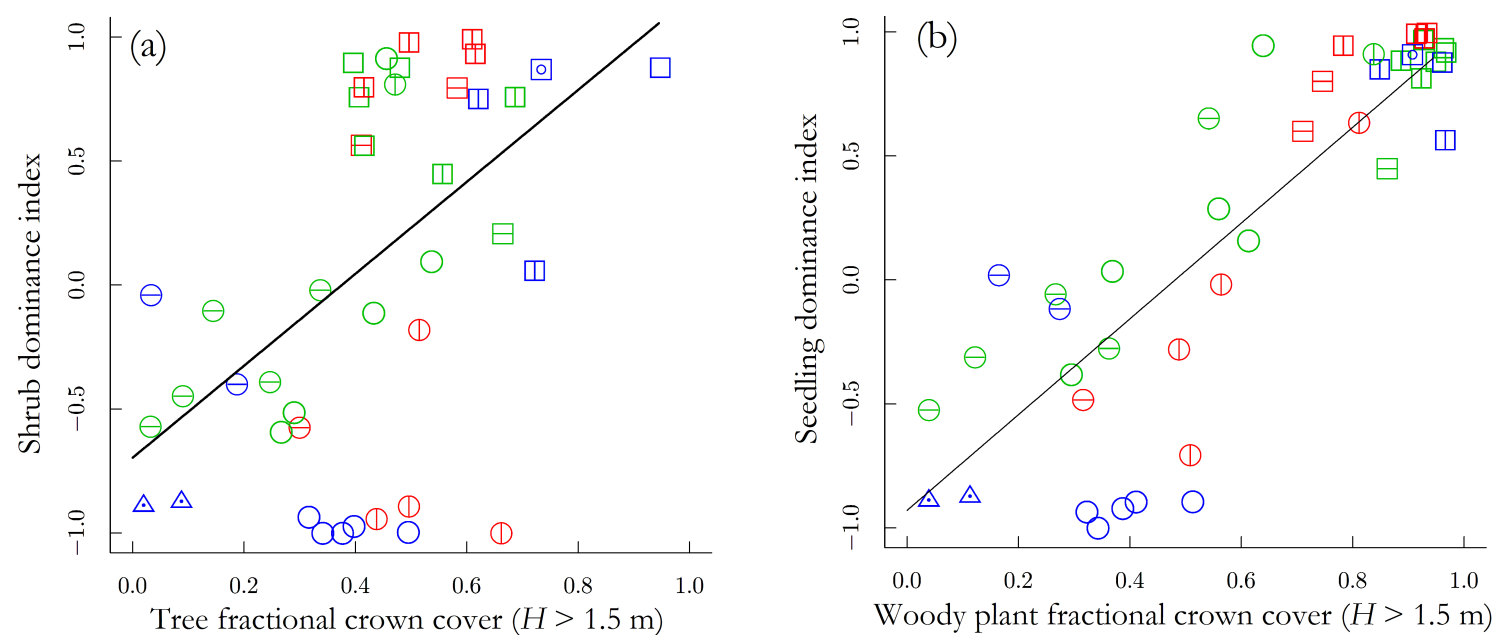

Figure 5. Relationships between upper stratum woody plant canopy dominance and measures of shrub/seedling competition in the lower layers. (a) Relationship between a shrub-dominance index $\left(\chi_{1}\right.$ : Eq. $\left.3 \mathrm{a}\right)$ and the total fractional cover of all tree species with a height $(H)>$ $1.5 \mathrm{~m}$; (b) a measure of (tree + shrub) seedling dominance ( $\chi_{2}$ : Eq. $\left.3 \mathrm{~b}\right)$ and the total woody crown cover $(H>1.5 \mathrm{~m})$. Symbols as in Fig. 1 . Lines represent of a linear robust (high breakpoint) regression fit to the data.
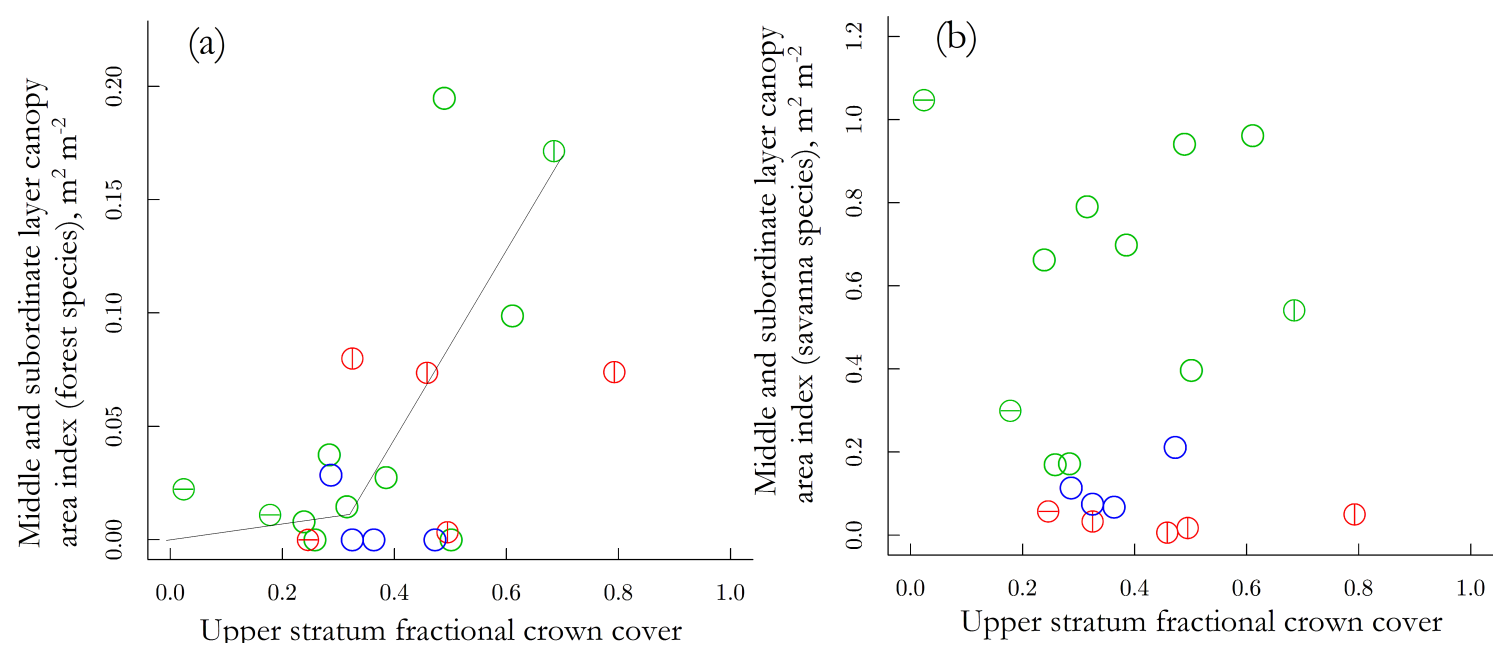

Figure 6. For plots characterised as savanna and located within ZOT, the relationship between upper stratum woody plant crown cover and (a) [middle + subordinate] forest-species canopy area index and (b) savanna species [middle + subordinate] layer canopy area index. Symbols as in Fig. 1. Note the different scales for the $y$ axes.

tinent, forest and savanna are shown separately and with plots located within ZOT shown by the shaded area (ZOT here defined as regions occurring at the intersection of major savanna-forest areas and with neither vegetation type clearly dominating at the scale of $10 \mathrm{~km}$ or less). Biomass estimates $(\hat{B})$ for each plot are also shown separately for the upper and middle strata and for lianas and with additional forest $\hat{B}$ (upper stratum only) coming from Feldpausch et al. (2012) indicated by an asterisk. Apart from showing that the ZOT investigated occur at different $W$ for different continents, the presence of stunted forests in areas significantly drier than the studied ZOT is illustrated, as is the occasional presence of savanna at low $W$. The most substantial increase in biomass associated with a transition from savanna to forest is for the South American ZOT (this being markedly less than for the sites sampled in Australia and Africa). There is also an important contribution of the middle stratum (trees and shrubs with $D<25 \mathrm{~mm}$ ) to the total biomass of plots within the ZOT in some cases as well as for the South American savannas in particular. 


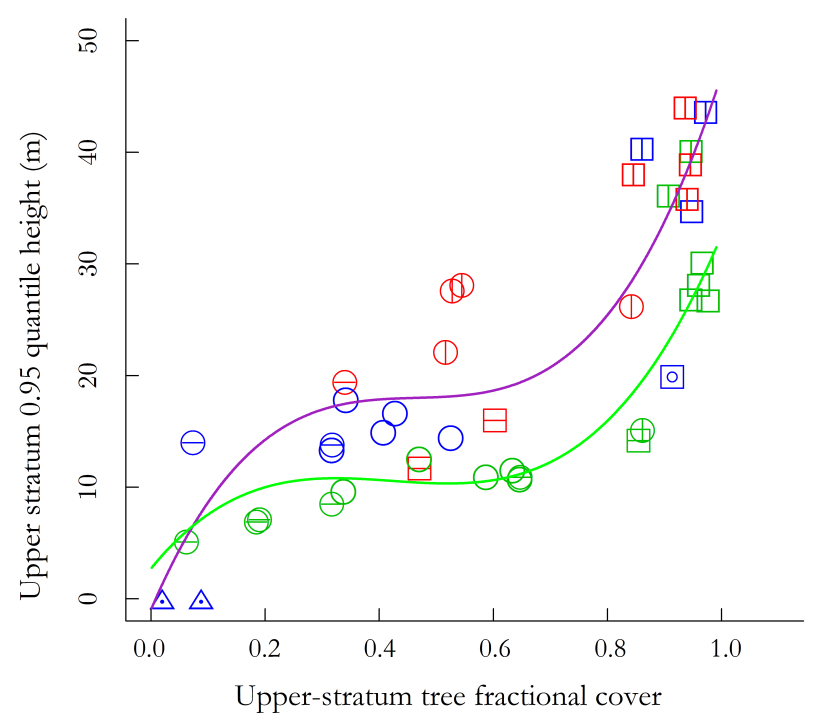

Figure 7. Relationship between the upper stratum 0.95 quantile height and total woody plant crown cover $(H>1.5 \mathrm{~m})$. Symbols as in Fig. 1. The lines show results of rank based linear model regression fits for which South America (green line) is significantly different to Africa and Australia $(p<0.05)$ which in turn do not differ from each other ( $p>0.1$ : purple line).

\subsection{Combined edaphic-climatic effects on tropical vegetation structure and the location of the forest-savanna boundary}

The location of all sampled plots in terms of both $W$ and soil cation nutrient status $\left(N^{+}\right.$; Eq. 4) is shown in Fig. 10. The $N^{+} \cap W$ environmental space encompassed by ZOT (as identified in Fig. 9) is shown by the shaded ellipse, with a fitted Standard Major Axis (SMA) regression line through these data points also shown. This indicates not only that the presence of the ZOT within South America at a more negative $W$ is associated with soils of a lower exchangeable base cation status, but also that variations in the locations of individual plots within ZOT on each continent are explicable in terms of the same $N^{+}-W$ relationship. Generally speaking, forests are found above the fitted line and savanna formation types below. Savannas were, however, found at higher $W$ for both South America and Australia, these stands being associated with low $N^{+}$. On the other hand, the stunted forests of both South America and Australia exist at relatively high $N^{+}$(and reasonably negative $W$ ). Also of note is a lack of observations where $W$ is strongly negative and $N^{+}$also low.

Figure 10 also shows a reasonably strong negative correlation between $N^{+}$and $W$ (Kendall's $\tau=0.46$ ) which has interesting implications for the inferences as to the relative importance of nutrient supply vs. water availability when analyses are considered as univariate predictors. This is shown in Fig. 11 where we have calculated across the entire data set (although excluding the treeless grasslands) both the ab- solute and partial Kendall's $\tau$ for canopy area index as a function of $N^{+}, W$ and soil plant available water storage $\left(\theta_{\mathrm{P}}\right)$, also with a $\theta_{\mathrm{P}} \times W$ interaction. This shows - quite remarkably - that although $N^{+}$can be considered as having no association with $C_{\mathrm{W}}$ when considered in an univariate sense $(\tau=0.01 ; p=0.461)$, once the effects of other deterministic covariates are controlled for through the calculation of a partial $\tau$, then $\mathrm{N}^{+}$assumes a prime significance ( $\tau=0.19 ; p=0.003$ ). In this partial Kendall's $\tau$ analysis, $W$ retains its significance as a predictor of $C_{\mathrm{W}}$ as is also the case for the $\theta_{\mathrm{P}} \times W$ interaction term of negative sign. With $W$ always having negative values in this data set, this can then be interpreted as indicating that soils with a high $\theta_{\mathrm{P}}$ are more effective in promoting a high $C_{\mathrm{W}}$ when $W$ is also high (i.e. with more favourable mean annual water balance).

The general notion that the location of forest-savanna transition zones may differ between continents is examined further in Fig. 12, where the frequency of occurrence of savanna vegetation formation types in terms of $P_{\mathrm{A}}$ is shown for all of Africa and South America binned into $0.2 \mathrm{~m} P_{\mathrm{A}}$ classes (original data from the vegetation map based study of Lloyd et al. (2008) undertaken at $1^{\circ} \times 1^{\circ}$ resolution). Here, observations to the right of the frequency diagrams are mostly foresttype vegetation types and those on the left arid vegetation type formations. This confirms a clear difference between the two continents in terms of savanna distribution in relation to rainfall. Specifically, the maximum frequency of savanna occurrence in South America is found at a $P_{\mathrm{A}}$ at least $0.2 \mathrm{~m}$ greater than for savannas in Africa. It was not, unfortunately, possible to include Australia in such an analysis due to the very limited area of tropical forest present.

\section{Discussion}

The idea that forest and savanna present fire-mediated alternate stable states has recently been supported by analyses of bi- or tri-model distributions of tree canopy cover in a remotely sensed global tree-cover data set (Hirota et al., 2011; Staver et al., 2011b; Murphy and Bowman, 2012) with this notion having been underwritten by models also simulating such dichotomies (Van Langevelde et al., 2003; Staver et al., 2011a; Higgins and Scheiter, 2012). This has led to the general view that such alternative stable states can exist under the same environmental conditions now becoming widespread see for example Warman and Moles (2009) and Hoffmann et al. (2012a). However, Hanan et al. (2013) have pointed out that gaps in the distribution patterns in the global tree-cover data set may be caused by statistical procedure rather than representing true abundance differences. Unequivocal evidence supporting the notion of alternative stable states should therefore be sought elsewhere.

Here we have reported a comprehensive set of observations of structural changes across savanna and forest formations across ZOT on three continents. Our expectation was 

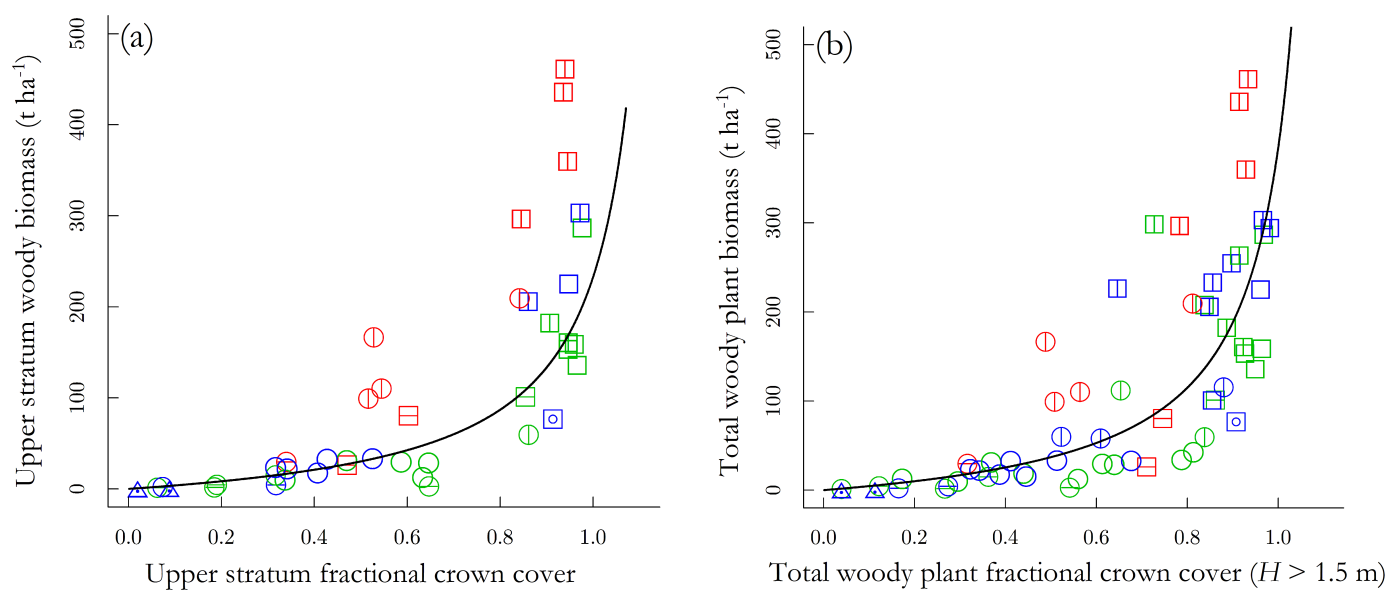

Figure 8. Relationship between (a) biomass and fractional crown cover for the upper-canopy stratum only, and (b) biomass and fractional cover for all trees and shrubs taller than $1.5 \mathrm{~m}$. Fitted curves represent a simple reciprocal relationship (viz. $1 / y=a+b / x)$ and have been fitted using a rank based linear model regression. Symbols as in Fig. 1.

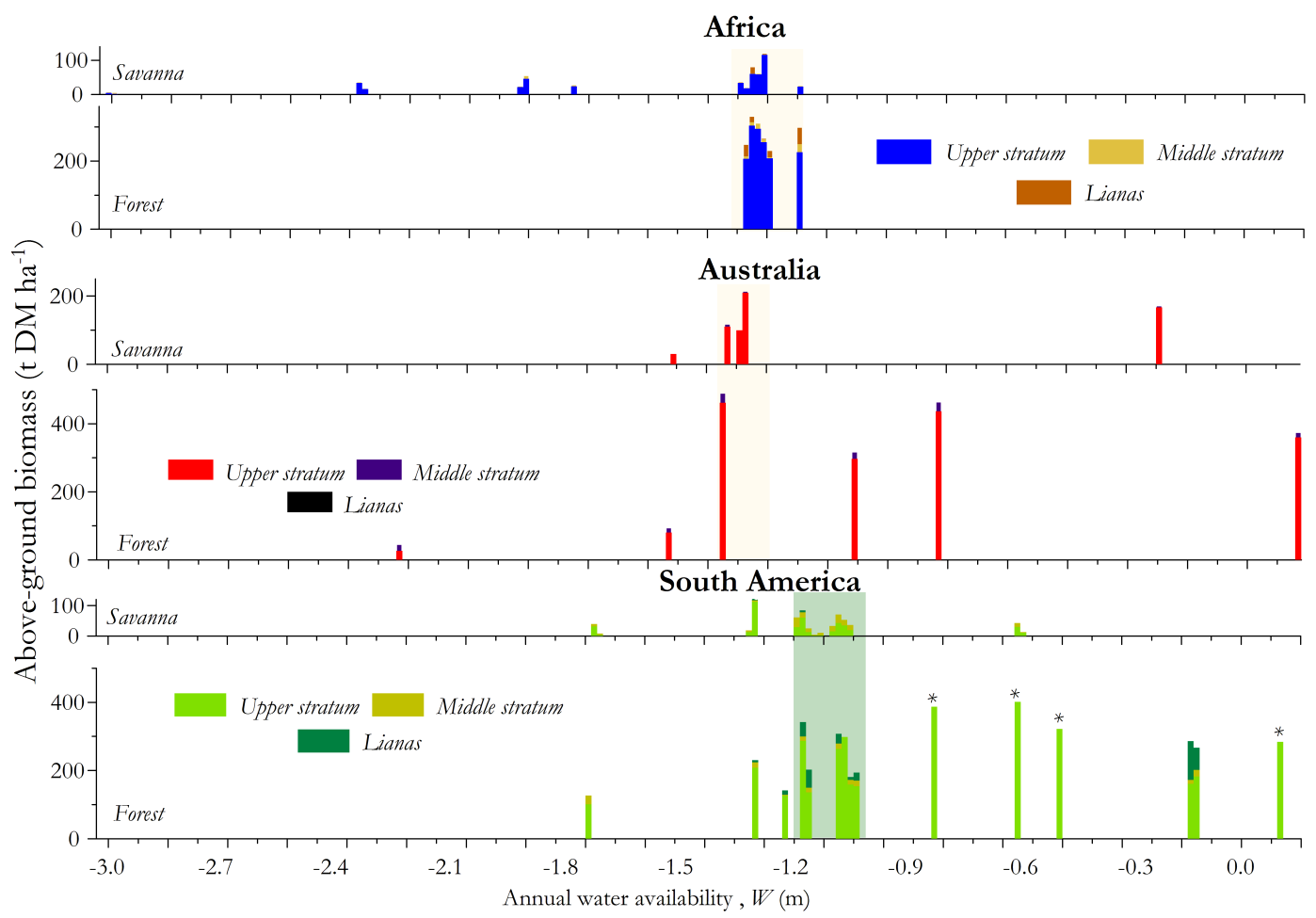

Figure 9. Variations in estimates of biomass of forest and savanna across the three continents; studies divided into the upper-canopy stratum (diameter at breast height, $D>0.1 \mathrm{~m})$, middle canopy stratum $(0.1 \mathrm{~m}<D<25 \mathrm{~mm})$ and lianas plotted as a function of mean annual water availability, $W$ (Eq. 3). For each continent, the approximate location of the main studied forest-savanna transition zone(s) are indicated by grey shading. For South America, extra sites at low $W$ (upper stratum only) have also been included and these are indicated by an asterisk.

that should alternative stable states driven by fire-mediated feedbacks exist, then associated with that should be abrupt disjunctions in vegetation structure observable across forestsavanna boundaries. Also, as argued previously by Warman and Moles (2009) and Murphy and Bowman (2012), it would not be expected that the studied zones of transition would be found located in some sort of consistently common climatesoil environmental space. 


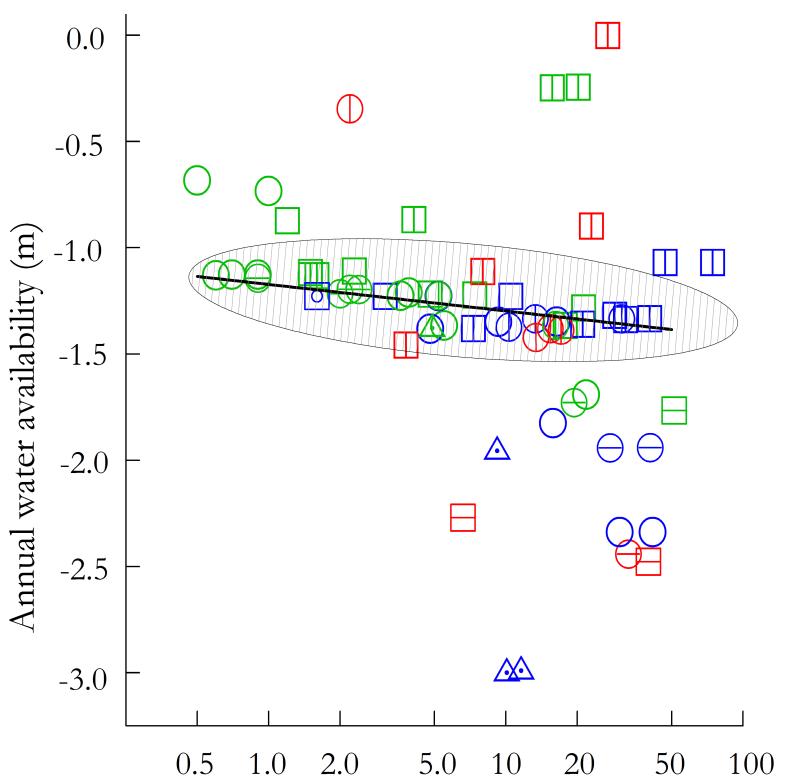

Total exchangable major nutrient cations (meq kg-1)

Figure 10. Location of sample plots in relation to their mean annual cumulative soil water deficit (defined as in Eq. 3) and exchangeable nutrient cation content for the top $0.3 \mathrm{~m}$ of soil (Eq. 4). Symbols as in Fig. 1. The ovoid encompasses all sites located within zones of transition as shown in the grey shading of Fig. 8 through which is also shown the best fit standard major axis regression line. Blue symbols: Africa; Green symbols: South America; Red symbols: Australia.

\subsection{Disjunction vs. continua in the forest-savanna transition}

In terms of evidence for disjunction of vegetation structure, Figs. 1 and 3 show much more a continuum, particularly if all layers of vegetation are taken into account. Specifically it would seem, around the point that canopy closure occurs, that the shrub layer of both forest and savanna becomes increasingly important (Fig. 3e), effectively replacing the grass layer in both woodland and open-forest systems (Figs. $3 \mathrm{f}$ and 5). Confounding comparisons with remote-sensing products is, however, the observation that many (shrub-dominated) savannas can have a considerable canopy cover, but with almost all of this contributed by trees $<5 \mathrm{~m}$ tall. Such low stature vegetation was apparently not included in the calibration of the global vegetation-cover data set of Hansen et al. (2003) and is presumably less accurately quantified as a result. This calls for caution when using such in silico data sets as a proxy for real world ecosystem level woody-cover measurements and the relative distribution of forest and savanna formations in zones of transition.

We do, of course, acknowledge that the transitional vegetation formations described in our study do not present a spatially complete frequency distribution of all savanna and forest formations present across the planet. They are, how-

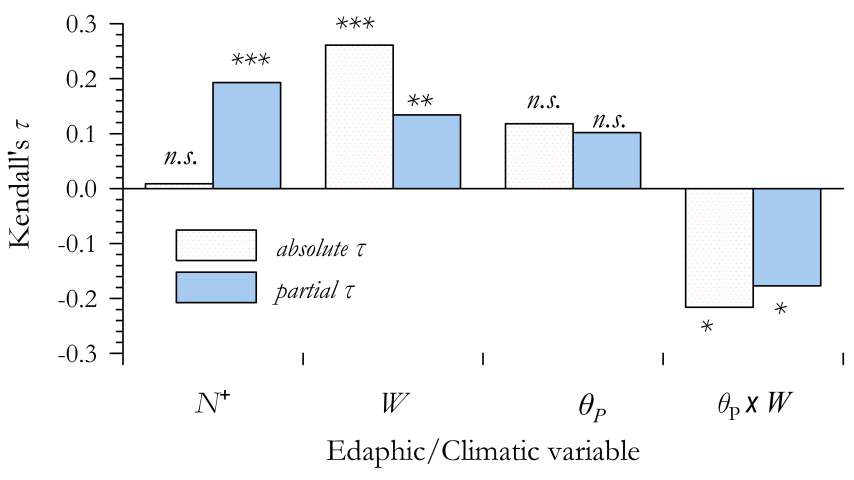

Figure 11. Absolute and partial Kendall's $\tau$ for the association between absolute and partial Kendall's $\tau$ for canopy area index as a function of exchangeable nutrient cation content $\left(N^{+}\right)$, mean annual cumulative soil water deficit $(W)$, soil plant available water storage $\left(\theta_{\mathrm{P}}\right)$ and a $\theta_{\mathrm{P}} \times W$ interaction term. Open red bars: absolute $\tau$; Closed blue bars: partial $\tau$; * is significant at $p<0.050$; ** is significant at $p<0.010$; *** is significant at $p<0.005$; n.s. is not significant $(p>0.05)$.

ever, representative of the commonly found formations in our study areas and were specifically selected for this purpose (Torello-Raventos et al., 2013). We therefore do not expect the analysis of the differences in structural layers as savanna transforms to forest to be fundamentally different in other sites. Most formations studied by us - with the exception of the MDJ-05 transitional forest plot in Central Africa, specifically selected as being in active transition (Mitchard et al., 2009) and NXV-02 in Brazil (Franczak et al., 2011) - can therefore be assumed, on the basis of history and stand age, to reflect the recent climate, soil and land management activities. Although soil organic matter ${ }^{13} \mathrm{C} /{ }^{12} \mathrm{C}$ ratios (G. Saiz and TROBIT Consortium, unpublished data) do suggest that some forest plots in Cameroon may have had savanna vegetation in the fairly recent (centennial timescale) past - see Table S1 as well as Torello-Raventos et al. (2013).

It might be argued that our analyses would have been significantly improved were we to have had, in addition to our extensive canopy and soil measurements, measures of fire histories for each plot. This was, indeed, attempted. But given the small plot size (typically $100 \mathrm{~m} \times 100 \mathrm{~m}$ ), available satellite-derived scar grids were found not to be of sufficient resolution for this purpose. We also attempted to deduce fire histories from aerial photographs, but again without success due to poor coverage and decadal-scale time intervals for most sites.

But in any case, what would accurate fire histories for each site have actually told us? Only that (presumably) grassier savannas tend to burn more. That observation by itself, however, can shed no light on the existence (or absence) of alternative stable states. This is because differences in fire frequency can legitimately be viewed as simply reflecting variations in vegetation structure (Lloyd et al., 2008): with these 


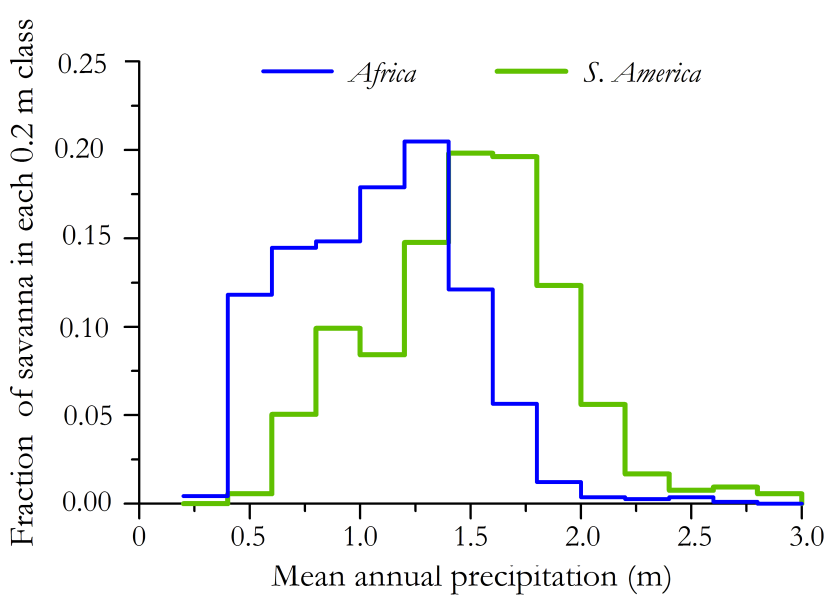

Figure 12. Distribution of savanna vegetation formation types (including grasslands) in Africa and South America in relation to mean annual precipitation. Original data from Lloyd et al. (2008).

vegetation variations in turn mediated by soils and climate. This is as opposed to fire being the prime cause of observed differences per se through strong feedback effects on vegetation structure leading to alternative stable states (Lehmann et al., 2011).

\subsection{Canopy closure, stand etiolation and the importance of the shrub layer}

The observed increase in understorey wood plant density around the stage of full upper-canopy closure is at the expense of the axylale cover and may be a consequence of the relative inefficiency of the $\mathrm{C}_{4}$ photosynthetic pathway typical of tropical grasses in shaded environments - as is also suggested by the finding that axylale species persisting in dense savanna and forest formations at relatively low abundances are of the $\mathrm{C}_{3}$ photosynthetic mode (Torello-Raventos et al., 2013). In this context we also note that Laubenfels (1975) working in North America and limiting his observations to "vegetation cover showing a minimum of disturbance, particularly by chopping, by heavy grazing and by fire" noted a natural discontinuity between "woodland" and "forest" in terms of their upper-canopy cover (the forest being "continuous" and the woodland "rarely more than $40 \%$ "). This transition was accompanied by substantial differences in understorey structure (changing from a dominance of grasses to that of shade-adapted understorey shrubs) analogous to those described here for the savanna-forest transformation. Effectively then, be it in the temperate zone or in the tropics, a new understorey environment is created around the stage that climatic and edaphic conditions combine to allow full upper-canopy closure to first occur. In both cases the resulting shaded understorey environment is very different to the high insolation and high evaporative demand ground layer of the more open-vegetation formation types. In the tropics this then favours relatively high canopy-cover shade-adapted $\mathrm{C}_{3}$ shrubs and - to a lesser extent $-\mathrm{C}_{3}$ grasses.

Put another way, as a result of a "new niche creation" at or around $C_{\mathrm{U}}=1$, it turns out that once conditions are suitably favourable for upper-canopy closure to be achieved, then a rapid increase in total stand-level woody plant cover ensues with a "filling up" of this newly created shaded understorey environment by suitably adapted woody species. Thus, when considering all woody canopy layers together, there is probably very little difference in the edaphic-climatic conditions necessary to support a stand of $C_{\mathrm{W}}=2$ as opposed to $C_{\mathrm{W}}=1$. And with fire-mediated feedbacks not necessary to account for this phenomenon.

Consistent with that notion is the rapid increase in canopy height that occurs around the point of canopy closure ( $\varsigma>$ 0.6 Fig. 7), this being observed for some savannas as well as forests. We interpret this as indicative of a rapid woody plant etiolation response initiated by a greatly increased competition for light once tree-to-tree canopy interactions become important. Here, we have the term "canopy etiolation" by analogy with the well-known adaptive response of seedlings to low-light conditions as is characterised by stem lengthening at the expense of foliar development as the young plant grows towards light (Leopold and Kriedemann, 1975). Thus, it is suggested that although in relatively moist forest systems with high levels of inter-tree competition that there may be good arguments for the maximum tree heights being limited by hydraulic constraints (Ryan and Yoder, 1997; Koch et al., 2004; Ryan et al., 2006); this does not mean that in drier savanna systems where trees are more isolated, that the typically shorter tree stature is also due to some sort of hydraulic constraint. Rather - with inter-tree competition light - tree height is then dictated solely by the leaf and/or reproductive area to be supported - this also depending on branch architectural patterns as dictated by Cantilever beam theory (Gere, 2004; Sterk et al., 2006; van Gelder et al., 2006). Consistent with this notion is the relative invariance of both canopy cover and tree height with precipitation on either side of the rapid transition area defining the etiolation response around $W=-1.3 \mathrm{~m} \mathrm{a}^{-1}$ (Fig. 2). That observation is not necessarily at odds with the study of Givnish et al. (2014) which showed the maximum height of southern Australian Eucalyptus stands to correlate to water availability. That study chose the very tallest/densest stands locatable in each of their study regions. Such "champion trees" have never been argued as representative of the region as a whole - also growing in what were no doubt unusually competitive stands for the climates sampled.

Figure 3 also suggests that beyond $C_{\mathrm{W}} \simeq 2$, the uppercanopy strata become increasingly dominant and with shadeadapted shrubs eventually out competed by taller shadeadapted tree species and a preponderance of regenerating seedlings representing species of all strata. Though interestingly the extent to which specialist shrubs can persist beneath 
the denser canopies of the moister tropical forests seems to vary from continent to continent (LaFrankie et al., 2006).

We also found evidence of the presence of forest species in the subordinate layers of some plots within ZOT but with savanna species dominating the upper stratum (Fig. 6a). This increase in the proportion of forest species with an increase in canopy closure could be taken to suggest that fire suppression, through a dense savanna tree upper canopy reducing herbaceous fuel loads (Fig. 3f), serves to promote the likelihood of survival of forest species. For this suggestion some empirical evidence exists (Hennenberg et al., 2006; Geiger et al., 2011). Alternatively, the increased abundance of understorey forest species relative to their savanna counterparts in such environments may simply be due to their typically greater shade tolerance (Hoffmann et al., 2012a, b) through the "niche creation" mechanism discussed above.

Nevertheless, rather than reflecting two clearly delineated alternatives maintained by feedback mechanisms, the presence of forest-like canopy structures dominated by savanna species, but with an appreciable abundance of forest species in the subordinate layers (though with a clear majority of such individuals not making it through to the upper-stratum stage), is much more indicative of a gradual "fading out" of fire effects on woody vegetation structure as conditions become progressively more favourable.

Although not always explicitly stated, theoretical models of fire-mediated feedbacks assume implicitly that stand structure and tree functional traits are correlated. For example, fire is argued to recur in savanna formation types through the persistence of flammable grasses which in turn require a relatively open canopy to reach a sufficient biomass for fires to be able to spread (Hennenberg et al., 2006; Hoffmann et al., 2012a). Necessarily associated with this are woody species with typical fire-adapted traits such as a relatively thick bark and a high re-sprouting ability as well as a high light requirement for growth (Ratnam et al., 2011; Hoffmann et al., 2012b). Our field data on vegetation formations in the ZOT show, however, that the supposed trait/canopy structure association is not obligatory. With some woodland formations dominated by species more usually associated with pyrogenic environments attaining forest like structures. Though sometimes also with an appreciable abundance of forest species in subordinate layers (Fig. 6). Our findings underline the importance of understanding canopy-cover closure differences in response to varying climatic drivers or $\mathrm{CO}_{2}$ increases (Higgins and Scheiter, 2012) as additional factors in the often cited explanation of fire reduction being the cause of the rapid expansion of forest species in the ZOT savanna woodlands of Central Africa, Australia (Mitchard et al., 2009; Bowman et al., 2010) or Brazil (Marimon et al., 2006).

\subsection{Allometry and above-ground biomass differences}

As a consequence of the dramatic increase in tree heights that occurs around the point of canopy closure (Fig. 7), for the reasons discussed in Sect. 4.2, forest vegetation formations generally showed a much higher above-ground biomass than savanna formations (Fig. 8) albeit with a smaller belowground trend in the opposite direction also likely (Lloyd et al., 2009). The transition of forest to savanna therefore has large implications for carbon stocks in above-ground vegetation (Fig. 9). As reported before in this study, woody biomass increases rapidly with canopy closure beyond a $\varsigma$ of 0.6 (Fig. 8). Within any particular region, $B$ for ZOT savanna vegetation formation types (sensu lato) are generally much less than for forests (Fig. 9), but globally speaking the variation in $B$ for both forest and savanna formation types within ZOT is large: with tall woodlands in Australia having a biomass similar to forests within South American ZOT. For both forest and savanna, the lower woody strata may contribute significantly to the total biomass (up to $20 \%$ ), this being particularly important for the South American plots. This may be of consequence not only for the accurate estimation of carbon losses associated with the extensive removal of such vegetation in the ZOT for economic development, but also for assessing changes in biomass associated with climate change induced shifts in vegetation distribution (Malhi et al., 2009). A better understanding of the savanna type replacing the forest vegetation is needed for such predictions to be accurate.

Continental differences were also observable with biomass and canopy height generally lower in South American plots compared to Africa and Australia. The tendency for South American trees to be shorter for a given $D$ (Fig. 7) has also been observed in tropical forest allometric studies (Feldpausch et al., 2011), and one possibility to account for this may be the extremely low cation status of many Amazonian forest and savanna soils (Cochrane, 1989; Quesada et al., 2010, 2011). The notion that nutrients limit the development of forest has been previously put forward through a simple analysis of total ecosystem nutrient stocks but with the overall evidence for this notion currently considered equivocal at best (Bond, 2010; Silva et al., 2013).

Contrasting allometric patterns in savanna tree crown diameter-height allometry have also been reported for Africa cf. Australia (Moncrieff et al., 2014). Together with the differences reported here and for tropical forest trees (Feldpausch et al., 2011; Banin et al., 2012), this means that the translation of tree height measurements made via light detection and ranging (lidar) remote-sensing methods into accurate stand-level woody biomass estimates (e.g. Khalefa et al., 2013) may not be straight forward. It is also clear that any meaningful attempt to identify drivers of variations in savanna biomass (or a proxy such as basal area) integrating data across the different continents will also need to take into account the much greater contributions of the small tree 
and shrub layer $(D<0.1 \mathrm{~m})$ shown to occur here for South American as compared to Australian and African savannas. Due to the non-linearities in their inter-relationships, care must also be given to the stand-level metric used in any intercomparison. For example, that higher woody plant abundances are typically associated with reduced fire regimes is attributable to their shading out of the axylale cover (Torello-Raventos et al., 2013) with associated reductions in fire spread rates and/or the frequency and intensity of fires (Govender et al., 2006; Archibald et al., 2010). Thus, one might reasonably argue that for the modelling of such feedbacks, fractional canopy cover is the appropriate metric. But with fire effects on stand-level biomass likely much greater than for foliage cover itself (Bond and Keeley, 2005). Likewise, even in the absence of significant effects of fire regime on woody biomass, it is unlikely that measurements of basal area or biomass relate in any simple way to differences in productivity as a consequence of differences in tree turnover times (Galbraith et al., 2013).

\subsection{Soils and the distribution of forest vs. savanna}

Biome distribution and ZOT locations differ between continents when considered in relation to climatic variables, in particular precipitation (Lloyd et al., 2008; Lehmann et al., 2011). Combining soil information on total base nutrient cations $\left(\mathrm{N}^{+}\right)$and $W$ in Fig. 10 shows, however, that the ZOT globally occurs across a consistent climate-soil space continuum with savannas predominating in drier and forest in wetter environments than the ZOT. Although savannas may vary greatly in biomass in the ZOT, the mere fact that this climatesoil space exists argues against the overriding importance of fire-mediated feedbacks as the main driver of forest savanna transitions. Moreover, when considering forest and savanna as a continuum, it turns out that although $N^{+}$is a poor predictor of $C_{\mathrm{W}}$ when considered on its own, once effects of water availability and soil water holding capacity are taken into account, $N^{+}$emerges as a key edaphic factor modulating $C_{\mathrm{W}}$ (Fig. 12). An ordination study by Lloyd et al. (2009) similarly showed soil cation status to be a key determinant of vegetation formation type distributions across tropical South America. Along with the clear implication of a (not so simple) influence of plant available soil water holding capacity on $C_{\mathrm{W}}$, a multitude of studies showed strong soil-vegetation associations at the local scale (e.g. Werger, 1978; Dowling et al., 1986, Le Roux et al., 1988; Coughenour and Ellis, 1993; White and Hood, 2004; Diouf et al., 2012; Clegg and O'Connor, 2012; Gandiwa et al., 2014), these soil cation effects - also having been reported before in a variety of guises (Goodland, 1973; Lopes and Cox, 1977; Cochrane, 1989; Mills et al., 2013) - mean that attempts to account for variations in tropical vegetation structure simply on the basis of easily measured climate and soil texture metrics (e.g. Sankaran et al., 2005; Lehmann et al., 2014) cannot be expected to succeed.
Of course, according to some rationales the implication of Fig. 11 that savanna-forest ecotones exist at different $P_{\mathrm{A}}$ for different continents could also be presented as some sort of evidence for fire-mediated feedbacks (Murphy and Bowman, 2012). Nevertheless, fires are actually much more common in the savanna regions of Africa than South America (Giglio et al., 2013) - the opposite of what would be expected if a greater intensity and/or frequency of fires was associated with ZOT occurring at higher $P_{\mathrm{A}}$. More likely as is indicated by Figs. 10 and $11-$ these intercontinental differences may be more associated with differences in soil cation availability as has also been suggested by Lehmann et al. (2011). This means that - until the principal interacting soil and climate factors influencing tropical vegetation structure are known - arguments that current savanna-forest distribution patterns provide some sort of evidence of alternative stable states and/or a dominant influence of fire (Bond et al., 2005; Murphy and Bowman, 2012; Lehmann et al., 2014) must be considered tenuous at best.

\section{Conclusions}

Sampling 61 savanna and forest plots across three continents, most of which (but not all) were located in the forest-savanna transition zone, we found a more gradual transition from forest to savanna vegetation formation types than is generally considered to be the case. This was mostly because of our inclusion of comprehensive measurements of the subordinate woody vegetation component which showed that shrubs progressively replace axylales as canopy closure occurs; and with the contribution of shrubs and subordinate trees to the total canopy area index in some cases being substantial. Moreover, it was also found that although there is a rapid increase in canopy height associated with the transition from savanna to forest, this was not uniquely associated with changes in community composition: with some stands dominated by savanna species achieving mean and 0.95 quantile heights similar to nearby forest. Moreover, with an observed lack of dependence of savanna community mean canopy heights on water availability across a wide range of evaporation deficits, it is suggested that - in the absence of inter-tree competition for light - that individual tree canopy heights are not determined primarily by hydraulic limitations, but rather primarily by structural imperatives relating to the adequate exposure of leaf and reproductive surface areas. Associated with this suggestion is the newly introduced concept of canopy etiolation, where it is argued that trees are required to assume a height greater than that required for their function as an isolated entity only at or beyond the point where soil and climate resources are sufficient to allow canopy closure to occur. With variations in the location of forest-savanna transition zones both within and between the different continents accountable in terms of differences in both evaporation deficit and soil cation status, it is further 
shown here that soil cation status and evaporation deficit-soil water storage interactions are similarly critical in accounting for variations in tropical woody vegetation canopy cover. We suggest that a failure to account for these effects may have led some authors to suppose an overly important role of fire as a driver of variations in tropical vegetation canopy structure.

Such conclusions are, of course, not necessarily at odds with the notion that the frequency and magnitude of fire both natural and anthropogenic - can substantially affect savanna vegetation structure. Nor is it at odds with the regular and persistent anthropogenic use of fire to maintain landscapes that would otherwise support forest vegetation formation types in a more open savanna-type state. But it is a case of a difference in viewpoint as to whether - through a series of feedback mechanisms - fire should be considered a prime driver giving rise to different vegetation types under the same climate cf. (in the absence of human intervention) the frequency and intensity of fire being considered much more a consequence of differences in vegetation structure than their ultimate cause. 
Appendix A: List of symbols used

\begin{tabular}{ll}
\hline Symbol/abbreviation & Meaning \\
\hline$a$ & annum \\
$a$ (subscript) & axylale layer (sum of all herbaceous components) \\
$B$ & above-ground biomass \\
$C_{\mathrm{W}}$ & woody plant canopy area index \\
$D$ & diameter at breast height \\
$D_{\mathrm{C}}$ & crown diameter \\
$H$ & tree height \\
$H^{*}$ & upper 0.95 quantile canopy height \\
$L$ & leaf area index \\
$\mathrm{m}$ & metre \\
$\mathrm{M}$ (subscript) & middle (canopy) layer $(0.1 \mathrm{~m}<D \leq 25 \mathrm{~mm}$ and $H>1.5 \mathrm{~m})$ \\
$N^{+}$ & total major nutrient cation concentration in soil (equation 4$)$ \\
$P_{\mathrm{A}}$ & mean annual precipitation \\
$\mathrm{S}($ subscript) & subordinate (canopy) layer $(H<1.5 \mathrm{~m}$ and/or $D<25 \mathrm{~mm})$ \\
$\mathrm{Se}($ subscript) & seedling \\
$\mathrm{Sh}($ subscript) & shrub \\
$\mathrm{t}($ subscript) & tree \\
$\mathrm{U}($ subscript) & upper (canopy) layer $(D \geq 0.1 \mathrm{~m})$ \\
$\mathrm{W}$ (subscript) & woody $(=U+M+S$ or $=t+$ Sh + Se) \\
$W$ & plant water supply in relation to evaporative demand $($ Eq. 3$)$ \\
$Z$ & canopy layer(s) \\
$Z$ ZOT & zone of (ecological) tension $($ a.k.a. zone of transition) \\
$\hat{x}$ & predicted value of variable $x$ \\
$\langle x\rangle$ & mean of variable $x$ \\
{$[x]_{\mathrm{E}}$} & equivalents of exchangeable element $x$ per unit soil dry matter \\
$\chi$ & shrub-dominance index $($ Eq. $2 \mathrm{a})$ \\
$\chi 2$ & seedling-dominance index $($ Eq. $2 \mathrm{~b})$ \\
$\alpha$ & average portion of skylight passing through a tree \\
$\zeta$ & fractional foliage cover (for trees, shrubs and seedlings $=\alpha 5)$ \\
$\rho$ & density \\
$S$ & fractional crown cover \\
\hline &
\end{tabular}




\section{The Supplement related to this article is available online at doi:10.5194/bg-12-2927-2015-supplement.}

Acknowledgements. This work was funded by the UK Natural Environment Research Council through a TROBIT Consortium grant (NE/D005590/1) administered by the University of Leeds. S. L. Lewis was funded by a Royal Society University Research Fellowship and E. M. Veenendaal received additional funding from the EU funded Geocarbon project (no. 283080). Part of the work in Mato Grosso, Brazil, was funded by PROCAD/CAPES and we also acknowledge the support and assistance of CSIR-Forestry Research Institute of Ghana (CSIR-FORIG) and Resource Management Support Centre of the Ghana Forestry Commission (FC-RMSC). WCS-Cameroon and J. Sonké provided logistical assistance in Cameroon and Annette den Holander provided fieldwork assistance in both Bolivia and Cameroon. Shiela Lloyd assisted with manuscript and figure preparation. We also thank Anthony Mills and three additional anonymous referees for comments which helped greatly improve the clarity of the final version.

Edited by: M. Bahn

\section{References}

Adejuwon, J. and Adesina, F.: The nature and dynamics of the forest-savanna boundary in south-western Nigeria, in: Nature and dynamics of forest-savanna boundaries, Chapman and Hall, London, 331-351, 1992.

Alexandre, D.-Y. and Kaïré, M.: Les productions des jachères africaines à climat soudanien (Boiset produits divers), in: La Jachère en Afrique Tropicale, edited by: Ch. Floret, R. P., John Libbey, Paris, 169-199, 2001.

Archibald, S., Nickless, A., Govender, N., Scholes, R. J., and Lehsten, V.: Climate and the inter-annual variability of fire in southern Africa: a meta-analysis using long-term field data and satellite-derived burnt area data, Global Ecol. Biogeogr., 19, 794-809, doi:10.1111/j.1466-8238.2010.00568.x, 2010.

Baddeley, A. and Turner, R.: Spatstat: an R package for analyzing spatial point patterns, J. Stat. Softw., 12, 1-42, 2005.

Banin, L., Feldpausch, T. R., Phillips, O. L., Baker, T. R., Lloyd, J., Affum-Baffoe, K., Arets, E. J. M. M., Berry, N. J., Bradford, M., Brienen, R. J. W., Davies, S., Drescher, M., Higuchi, N., Hilbert, D. W., Hladik, A., Iida, Y., Abu Salim, K., Kassim, A. R., King, D. A., Lopez-Gonzalez, G., Metcalfe, D., Nilus, R., Peh, K. S.-H., Reitsma, J. M., Sonk, B., Taedoumg, H., Tan, S., White, L., Wöll, H., and Lewis, S. L.: What controls tropical forest architecture? Testing environmental structural and floristic drivers, Global Ecol. Biogeogr., 21, 11791190, doi:10.1111/j.1466-8238.2012.00778.x, 2012.

Berry, S. L. and Roderick, M. L.: Estimating mixtures of leaf functional types using continental-scale satellite and climatic data, Global Ecol. Biogeogr., 11, 23-39, 2002.

Bertram, J. and Dewar, R. C.: Statistical patterns in tropical tree cover explained by the different water demand of individual trees and grasses, Ecology, 94, 2138-2144, doi:10.1890/13-0379.1, 2013.
Bivand, R. S., Pebesma, E. J., and Rubio, V. G.: Applied Spatial Data: Analysis with R, Springer, 2008.

Bond, W.: Do nutrient-poor soils inhibit development of forests? A nutrient stock analysis, Plant Soil, 334, 47-60, doi:10.1007/s11104-010-0440-0, 2010.

Bond, W. J. and Keeley, J. E.: Fire as a global herbivore: the ecology and evolution of flammable ecosystems, Trends Ecol. Evol., 20, 387-394, 2005.

Bond, W. J., Woodward, F. I., and Midgley, G. F.: The global distribution of ecosystems in a world without fire, New Phytol., 165, 525-538, 2005.

Bowman, D. M., Murphy, B. P., and Banfai, D. S.: Has global environmental change caused monsoon rainforests to expand in the Australian monsoon tropics?, Landscape Ecol., 25, 1247-1260, 2010.

Chave, J., Andalo, C., Brown, S., Cairns, M. A., Chambers, J. Q., Eamus, D., Folster, H., Fromard, F., Higuchi, N., Kira, T., Lescure, J. P., Nelson, B. W., Ogawa, H., Puig, H., Riera, B., and Yamakura, T.: Tree allometry and improved estimation of carbon stocks and balance in tropical forests, Oecologia, 145, 87-99, doi:10.1007/s00442-005-0100-x, 2005.

Clegg, B. and O'Connor, T.: The vegetation of Malilangwe Wildlife Reserve, south-eastern Zimbabwe, African Journal of Range and Forage Science, 29, 109-131, 2012.

Cochrane, T. T.: Chemical properties of native savanna and forest soils in central Brazil, Soil Sci. Soc. Am. J., 53, 139-141, 1989.

Conover, W. J.: Practical Non-Parametric Statistics, 2nd edn. John Wiley and Sons, New York, 492 pp., 1980.

Coughenour, M. B. and Ellis, J. E.: Landscape and climatic control of woody vegetation in a dry tropical ecosystem: Turkana District, Kenya, J. Biogeogr., 383-398, 1993.

de Castilho, C. V., Magnusson, W. E., de Araújo, R. N. O., Luizao, R. C., Luizao, F. J., Lima, A. P., and Higuchi, N.: Variation in aboveground tree live biomass in a central Amazonian Forest: effects of soil and topography, Forest Ecol. Manag., 234, 85-96, 2006.

Diouf, A., Barbier, N., Lykke, A. M., Couteron, P., Deblauwe, V., Mahamane, A., Saadou, M., and Bogaert, J.: Relationships between fire history, edaphic factors and woody vegetation structure and composition in a semi-arid savanna landscape (Niger, West Africa), Appl. Veg. Sci., 15, 488-500, doi:10.1111/j.1654109X.2012.01187.x, 2012.

Dowling, A. J., Webb, A. A., and Scanlan, J. C.: Surface soil chemical and physical patterns in a brigalow-Dawson gum forest, central Queensland, Aust. J. Ecol., 11, 155-162, doi:10.1111/j.14429993.1986.tb01386.x, 1986.

Du Rietz, G. E.: Classification and nomenclature of vegetation units 1930-1935, Sven. Bot. Tidskr., 30, 580-589, 1936.

Eiten, G.: The Cerrado vegetation of Brazil, Bot. Rev., 38, 201-341, 1972.

Fairhead, J. and Leach, M.: Misreading the African landscape: Society and ecology in a forest-savanna mosaic, Cambridge University Press, 1996.

Falster, D. S. and Westoby, M.: Plant height and evolutionary games, Trends Ecol. Evol., 18, 337-343, 2003.

Feldpausch, T. R., Banin, L., Phillips, O. L., Baker, T. R., Lewis, S. L., Quesada, C. A., Affum-Baffoe, K., Arets, E. J. M. M., Berry, N. J., Bird, M., Brondizio, E. S., de Camargo, P., Chave, J., Djagbletey, G., Domingues, T. F., 
Drescher, M., Fearnside, P. M., França, M. B., Fyllas, N. M., Lopez-Gonzalez, G., Hladik, A., Higuchi, N., Hunter, M. O., Iida, Y., Salim, K. A., Kassim, A. R., Keller, M., Kemp, J., King, D. A., Lovett, J. C., Marimon, B. S., MarimonJunior, B. H., Lenza, E., Marshall, A. R., Metcalfe, D. J., Mitchard, E. T. A., Moran, E. F., Nelson, B. W., Nilus, R., Nogueira, E. M., Palace, M., Patiño, S., Peh, K. S.-H., Raventos, M. T., Reitsma, J. M., Saiz, G., Schrodt, F., Sonké, B., Taedoumg, H. E., Tan, S., White, L., Wöll, H., and Lloyd, J.: Height-diameter allometry of tropical forest trees, Biogeosciences, 8, 1081-1106, doi:10.5194/bg-8-1081-2011, 2011.

Feldpausch, T. R., Lloyd, J., Lewis, S. L., Brienen, R. J. W., Gloor, E., Monteagudo Mendoza, A., Lopez-Gonzalez, G., Banin, L., Abu Salim, K., Affum-Baffoe, K., Alexiades, M., Almeida, S., Amaral, I., Andrade, A., Aragão, L. E. O. C., Araujo Murakami, A., Arets, E. J. M. M., Arroyo, L., G. A. Aymard C., Baker, T. R., Bánki, O. S., Berry, N. J., Cardozo, N., Chave, J., Comiskey, J. A., Dávila, E. A., de Oliveira, A., DiFiore, A., Djagbletey, G., Domingues, T. F., Erwin, T. L., Fearnside, P. M., França, M. B., Freitas, M.A., Higuchi, N., E. Honorio C., Iida, Y., Jiménez, E., Kassim, A. R., Killeen, T. J., Laurance, W. F., Lovett, J. C., Malhi, Y., Marimon, B. S., Marimon-Junior, B. H., Lenza, E., Marshall, A. R., Mendoza, C., Metcalfe, D. J., Mitchard, E. T. A., Nelson, B. W., Nilus, R., Nogueira, E. M., Parada, A., Peh, K. S.-H., Pena Cruz, A., Peñuela, M. C., Pitman, N. C. A., Prieto, A., Quesada, C.A., Ramírez, F., Ramírez-Angulo, H., Reitsma, J. M., Rudas, A., Saiz, G., Salomão, R. P., Schwarz, M., Silva, N., Silva-Espejo, J. E., Silveira, M., Sonké, B., Stropp, J., Taedoumg, H. E., Tan, S., ter Steege, H., Terborgh, J., Torello-Raventos, M., van der Heijden, G. M. F., Vásquez, R., Vilanova, E., Vos, V., White, L., Wilcock, S., Woell, H., and Phillips, O. L.: Tree height integrated into pan-tropical forest biomass estimates, Biogeosciences Discuss., 9, 2567-2622, doi:10.5194/bgd-9-2567-2012, 2012

Fensham, R. J.: Floristics and environmental relations of inland dry rainforest in north Queensland, Australia, J. Biogeogr., 22, 10471063, 1995.

Franco, A., Rossatto, D., de Carvalho Ramos Silva, L., and da Silva Ferreira, C.: Cerrado vegetation and global change: the role of functional types, resource availability and disturbance in regulating plant community responses to rising $\mathrm{CO}_{2}$ levels and climate warming, Theor. Exp. Plant Physiol, 26, 19-38, doi:10.1007/s40626-014-0002-6, 2014.

Franczak, D. D., Marimon, B. S., Marimon-Junior, B. H., Mews, H. A., Maracahipes, L., and de Oliveira, E. A.: Mudanças na estrutura de um cerradão em um período de seis anos, na transição Cerrado-Floresta Amazônica, Mato Grosso, Brasil, Rodriguésia-Instituto de Pesquisas Jardim Botânico do Rio de Janeiro, 62, 2011.

Frazer, G. W., Canham, C. D., and Lertzman, K. P.: Gap Light Analyzer (GLA), Version 2.0: Imaging Software to Extract Canopy Structure and Gap Light transmission Indices from True-colour Fisheye Photographs, User's Manual and Program Documentation, Simon Fraser University, Burnaby, British Columbia, and the Institute of Ecosystem Studies, Millbrook, New York, 1999.

Furley, P. A., and Ratter, J. A.: Soil resources and plant communities of the central Brazilian cerrado and their development, J. Biogeogr., 97-108, 1988.
Galbraith, D., Malhi, Y., Affum-Baffoe, K., Castanho, A. D. A., Doughty, C. E., Fisher, R. A., Lewis, S. L., Peh, K. S. H., Phillips, O. L., Quesada, C. A., Sonk, B., and Lloyd, J.: Residence times of woody biomass in tropical forests, Plant Ecol. Divers., 6, 139157, doi:10.1080/17550874.2013.770578, 2013.

Gandiwa, E., Zisadza-Gandiwa, P., Goza, D., Mashapa, C., and Muboko, N.: Diversity and structure of woody vegetation across areas with different soils in Gonarezhou National Park, Zimbabwe, Southern Forests: a Journal of Forest Science, 76, 111116, doi:10.2989/20702620.2014.921007, 2014.

Gee, G. W. and Bauder, J. W.: Particle-size analysis, in: Methods in Soil Analysis, Part 1, Physical and Mineralogical Methods, edited by: Klute, A., American Society of Agronomy and Soil Science Society of America, Madison, Wisconsin, USA, 383409, 1986.

Geiger, E. L., Gotsch, S. G., Damasco, G., Haridasan, M., Franco, A. C., and Hoffmann, W. A.: Distinct roles of savanna and forest tree species in regeneration under fire suppression in a Brazilian savanna, J. Veg. Sci., 22, 312-321, doi:10.1111/j.1654-1103.2011.01252.x, 2011.

Gentry, A. H.: Diversity and floristic composition of neotropical dry forests, in: Seasonally Dry Tropical Forests, edited by: Bullock, S., Mooney, H. A., and Medina, E., Cambridge University Press, 146-194, 1995.

Gere, J. M.: Mechanics of Materials, Brooks, London, 2004.

Giglio, L., Randerson, J. T., and Werf, G. R.: Analysis of daily, monthly, and annual burned area using the fourth-generation global fire emissions database (GFED4), J. Geophys. Res.Biogeo., 118, 317-328, 2013.

Gignoux, J., Lahoreau, G., Julliard, R., and Barot, S.: Establishment and early persistence of tree seedlings in an annually burned savanna, J. Ecol., 97, 484-495, 2009.

Givnish, T. J., Wong, S. C., Stuart-Williams, H., Holloway-Phillips, M., and Farquhar, G. D.: Determinants of maximum tree height in Eucalyptus species along a rainfall gradient in Victoria, Australia, Ecology, 95, 2991-3007, doi:10.1890/14-0240.1, 2014.

Gloor, M., Gatti, L., Brienen, R., Feldpausch, T. R., Phillips, O. L., Miller, J., Ometto, J. P., Rocha, H., Baker, T., de Jong, B., Houghton, R. A., Malhi, Y., Aragão, L. E. O. C., Guyot, J.L., Zhao, K., Jackson, R., Peylin, P., Sitch, S., Poulter, B., Lomas, M., Zaehle, S., Huntingford, C., Levy, P., and Lloyd, J.: The carbon balance of South America: a review of the status, decadal trends and main determinants, Biogeosciences, 9, 54075430, doi:10.5194/bg-9-5407-2012, 2012.

Goodland, R. and Pollard, R.: The Brazilian cerrado vegetation: a fertility gradient, J. Ecol., 219-224, 1973.

Govender, N., Trollope, W. S. W., and Van Wilgen, B. W.: The effect of fire season, fire frequency, rainfall and management on fire intensity in savanna vegetation in South Africa, J. Appl. Ecol., 43, 748-758, doi:10.1111/j.1365-2664.2006.01184.x, 2006.

Haase, R. and Beck, G.: Structure and composition of savanna vegetation in northern Bolivia: a preliminary report, Brittonia, 41, 80-100, doi:10.2307/2807594, 1989.

Hanan, N. P., Tredennick, A. T., Prihodko, L., Bucini, G., and Dohn, J.: Analysis of stable states in global savannas: is the CART pulling the horse?, Global Ecol. Biogeogr., 23, 259-263, 2013.

Hansen, M. C., DeFries, R. S., Townshend, J. R. G., Marufu, L., and Sohlberg, R.: Development of a MODIS tree cover validation 
data set for Western Province, Zambia, Remote Sens. Environ., 83, 320-335, 2002.

Hansen, M. C., DeFries, R. S., Townshend, J. R. G., Carroll, M., Dimiceli, C., and Sohlberg, R. A.: Global percent tree cover at a spatial resolution of 500 meters: first results of the MODIS vegetation continuous fields algorithm, Earth Interact., 7, 1-15, doi:10.1175/1087-3562(2003)007<0001:GPTCAA>2.0.CO;2, 2003.

Hennenberg, K. J., Fischer, F., Kouadio, K., Goetze, D., Orthmann, B., Linsenmair, K. E., Jeltsch, F., and Porembski, S.: Phytomass and fire occurrence along forest-savanna transects in the Comoé National Park, Ivory Coast, J. Trop. Ecol., 22, 303-311, 2006.

Henry, M., Picard, N., Trotta, C., Manlay, R. J., Valentini, R., Bernoux, M., and Saint-André, L.: Estimating Tree Biomass of Sub-Saharan African Forests: a Review of Available Allometric Equations, Finnish Society of Forest Science, 2011.

Higgins, S. I. and Scheiter, S.: Atmospheric $\mathrm{CO}_{2}$ forces abrupt vegetation shifts locally, but not globally, Nature, 488, 209-212, 2012.

Hirota, M., Holmgren, M., Van Nes, E. H., and Scheffer, M.: Global resilience of tropical forest and savanna to critical transitions, Science, 334, 232-235, doi:10.1126/science.1210657, 2011.

Hodnett, M. G. and Tomasella, J.: Marked differences between van Genuchten soil water-retention parameters for temperate and tropical soils a new water-retention pedo-transfer functions developed for tropical soils, Geoderma, 108, 155-180, doi:10.1016/S0016-7061(02)00105-2, 2002.

Hoffmann, W. A., Adasme, R., Haridasan, M., T. de Carvalho, M., Geiger, E. L., Pereira, M. A. B., Gotsch, S. G., and Franco, A. C.: Tree topkill, not mortality, governs the dynamics of savannaforest boundaries under frequent fire in central Brazil, Ecology, 90, 1326-1337, doi:10.1890/08-0741.1, 2009.

Hoffmann, W. A., Geiger, E. L., Gotsch, S. G., Rossatto, D. R., Silva, L. C., Lau, O. L., Haridasan, M., and Franco, A. C.: Ecological thresholds at the savanna-forest boundary: how plant traits, resources and fire govern the distribution of tropical biomes, Ecol. Lett., 15, 759-768, 2012a.

Hoffmann, W. A., Jaconis, S. Y., McKinley, K. L., Geiger, E. L., Gotsch, S. G., and Franco, A. C.: Fuels or microclimate? Understanding the drivers of fire feedbacks at savanna-forest boundaries, Austral Ecol., 37, 634-643, doi:10.1111/j.14429993.2011.02324.x, 2012b.

Hopkins, B.: Ecological processes at the forest-savanna boundary, in: Nature and Dynamics of Forest-Savanna Boundaries, edited by: Furley, P., Proctor, J., and Ratter, J. A., Chapman and Hall, London, 21-34, 1992.

Hopkins, B. and Jenkin, R. N.: Vegetation of the Olokemeji Forest Reserve, Nigeria: I. General features of the reserve and the research sites, J. Ecol., 50, 559-598, doi:10.2307/2257471, 1962.

Houghton, R.: Carbon emissions and the drivers of deforestation and forest degradation in the tropics, Current Opinion in Environmental Sustainability, 4, 597-603, 2012.

Ilic, J., Boland, D., McDonald, M., Downes, G., and Blakemore, P.: Wood density phase 1 - state of knowledge, Technical Report No. 18, National Carbon Accounting System, Canberra, 2000.

Ingrouille, M. J. and Eddie, B.: Plants: Diversity and Evolution, Cambridge University Press, Cambridge, 2006.
Kellman, M.: Synergistic relationships between fire and low soil fertility in neotropical savannas: a hypothesis, Biotropia, 158160, 1984.

Khalefa, E., Smit, I. P. J., Nickless, A., Archibald, S., Comber, A., and Balzter, H.: Retrieval of Savanna Vegetation Canopy Height from ICESat-GLAS Spaceborne LiDAR With Terrain Correction, Geosci. Remote Sens. Lett., IEEE, 10, 1439-1443, doi:10.1109/LGRS.2013.2259793, 2013.

Killeen, T. J., Jardim, A., Mamani, F., and Rojas, N.: Diversity, composition and structure of a tropical semideciduous forest in the Chiquitania region of Santa Cruz, Bolivia, J. Trop. Ecol., 14, 803-827, 1998.

Killeen, T. J., Chavez, E., Peña-Claros, M., Toledo, M., Arroyo, L., Caballero, J., Correa, L., Guillén, R., Quevedo, R., and Saldias, M.: The Chiquitano dry forest, the transition between humid and dry forest in eastern lowland Bolivia, in: Neotropical Savannas and Seasonally Dry Forests: Plant Diversity, Biogeography, and Conservation, edited by: Pennington, R. T., Lewis, G. P., and Ratter, J. A., CRC Press, Boca Rato, 213-233, 2006.

Koch, G. W., Sillett, S. C., Jennings, G. M., and Davis, S. D.: The limits to tree height, Nature, 428, 851-854, doi:10.1038/nature02417, 2004.

LaFrankie, J. V., Ashton, P. S., Chuyong, G. B., Co, L., Condit, R., Davies, S. J., Foster, R., Hubbell, S. P., Kenfack, D., and Lagunzad, D.: Contrasting structure and composition of the understorey in species-rich tropical rain forests, Ecology, 87, 22982305, 2006.

Laubenfels, D. D.: Mapping the World's Vegetation, Regionalization of Formations and Flora, Syracuse University Press, Syracuse, New York, 1975.

Le Roux, C., Grunow, J., Morris, J., Bredenkamp, G., and Scheepers, J.: Classification of the vegetation of the Etosha National Park, S. Afr. J. Bot., 54, 1-10, 1988.

Legendre, P. and Legendre, L.: Numerical Ecology, Elsevier, Amsterdam, 2012.

Lehmann, C. E. R., Archibald, S. A., Hoffmann, W. A., and Bond, W. J.: Deciphering the distribution of the savanna biome, New Phytol., 191, 197-209, doi:10.1111/j.14698137.2011.03689.x, 2011.

Lehmann, C. E. R., Anderson, T. M., Sankaran, M., Higgins, S. I., Archibald, S., Hoffmann, W. A., Hanan, N. P., Williams, R. J., Fensham, R. J., and Felfili, J.: Savanna Vegetation-Fire-Climate Relationships Differ Among Continents, Science, 343, 548-552, 2014.

Leopold, A. C. and Kriedemann, P. E.: Plant Growth and Development, McGraw-Hill, New York, 1975.

Lloyd, J., Bird, M. I., Vellen, L., Miranda, A. C., Veenendaal, E. M., Djagbletey, G., Miranda, H. S., Cook, G., and Farquhar, G. D. Contributions of woody and herbaceous vegetation to tropical savanna ecosystem productivity: a quasi-global estimate, Tree Physiol., 28, 451-468, doi:10.1093/treephys/28.3.451, 2008.

Lloyd, J., Goulden, M., Ometto, J. P., Fyllas, N. M., Quesada, C. A., and Patino, S.: Ecophysiology of forest and savanna vegetation, in: Amazonia and Climate Change, edited by: Keller, M., Gash, J., and Silva Dias, P., American Geophysical Union, Washington DC, 463-484, 2009.

Lopes, A. and Cox, F.: Cerrado vegetation in Brazil: an edaphic gradient, Agronomy Journal, 69, 828-831, 1977. 
Louppe, D., Oattara, N., and Coulibaly, A.: The effects of brush fires on vegetation: the Aubréville fire plots after 60 years, Commonwealth Forestry Review 74, 288-292, 1995.

Maghsoodloo, S. and Laszlo Pallos, L.: Asdymtotic behaviour of Kendall' partial rank co rrelation coefficient and additional quantile estimates, J. Stat. Comput. Simul. 13, 41-48, 1981.

Malhi, Y.: The carbon balance of tropical forest regions, 19902005, Current Opinion in Environmental Sustainability, 2, $237-$ 244, 2010 .

Malhi, Y., Aragão, L. E., Galbraith, D., Huntingford, C., Fisher, R., Zelazowski, P., Sitch, S., McSweeney, C., and Meir, P.: Exploring the likelihood and mechanism of a climate-change-induced dieback of the Amazon rainforest, P. Natl. Acad. Sci. USA, 106, 20610-20615, 2009.

Malimbwi, R., Solberg, B., and Luoga, E.: Estimation of biomass and volume in miombo woodland at Kitulangalo Forest Reserve, Tanzania, J. Trop. For. Sci., 7, 230-242, 1994.

Marimon, B., de Slima, E., Duarte, T., Chieregatto, L., and Ratter, J.: Observations on the vegetation of northeastern Mato Grosso, Brazil. IV. An analysis of the Cerrado-Amazonian Forest ecotone, Edin. J. Bot., 63, 323-341, 2006.

May, R. M.: Stability and Complexity in Model Ecosystems, Princeton University Press, 2001.

Menaut, J.-C.: Etude de Quelques Peuplements Ligneux d'une Savane Guineenne de Corte d'Ivoire, Faculte des Sciences de Paris, Paris, France, 1971.

Mills, A. J., Milewski, A. V., Fey, M. V., Gröngörft, A., Petersen, A., and Sirami, C.: Constraint on woody cover in relation to nutrient content of soils in western southern Africa, Oikos, 122, 136-148, doi:10.1111/j.1600-0706.2012.20417.x, 2013.

Mitchard, E., Saatchi, S., Gerard, F., Lewis, S., and Meir, P.: Measuring woody encroachment along a forest-savanna boundary in Central Africa, Earth Interact., 13, 1-29, 2009.

Moncrieff, G. R., Lehmann, C. E., Schnitzler, J., Gambiza, J., Hiernaux, P., Ryan, C. M., Shackleton, C. M., Williams, R. J., and Higgins, S. I.: Contrasting architecture of key African and Australian avanna tree taxa drives intercontinental structural divergence, Global Ecol. Biogeogr., 23, 1235-1244, 2014.

Muggeo, V.: Segmented: an R package to fit regression models with broken-line relationships, R News, 8, 20-25, 2008.

Murdoch, G., Ojo Atere, J., Colborne, G., Olomu, E., and Odugbesan, E.: Soils of the Western State savanna in Nigeria, Volume 1, The environment, Land Resource Study (UK), no. 23, 1976.

Murphy, B. P. and Bowman, D. M.: What controls the distribution of tropical forest and savanna?, Ecol. Lett., 15, 748-758, 2012.

Oberle, B., Grace, J. B., and Chase, J. M.: Beneath the veil: plant growth form influences the strength of species richnessproductivity relationships in forests, Global Ecol. Biogeogr., 18, 416-425, 2009.

Pachzelt, A., Rammig, A., Higgins, S., and Hickler, T.: Coupling a physiological grazer population model with a generalized model for vegetation dynamics, Ecol. Model., 263, 92-102, 2013.

Pinheiro, J., Bates, D., DebRoy, S., Sarkar, D., and R Core Team: Linear and Nonlinear Mixed Effects Models, R package version 3.1-120, http://CRAN.R-project.org/package=nlme, 2015.

Pleysier, J. L. and Juo, A. S. R.: A single-extraction method using silver-thiourea for measuring exchangeable cations and effec- tive CEC in soils with variable charges, Soil Sci., 129, 205-211, 1980.

Quesada, C. A., Lloyd, J., Schwarz, M., Patiño, S., Baker, T. R., Czimczik, C., Fyllas, N. M., Martinelli, L., Nardoto, G. B., Schmerler, J., Santos, A. J. B., Hodnett, M. G., Herrera, R., Luizão, F. J., Arneth, A., Lloyd, G., Dezzeo, N., Hilke, I., Kuhlmann, I., Raessler, M., Brand, W. A., Geilmann, H., Moraes Filho, J. O., Carvalho, F. P., Araujo Filho, R. N., Chaves, J. E., Cruz Junior, O. F., Pimentel, T. P., and Paiva, R.: Variations in chemical and physical properties of Amazon forest soils in relation to their genesis, Biogeosciences, 7, 1515-1541, doi:10.5194/bg-7-15152010, 2010.

Quesada, C. A., Lloyd, J., Anderson, L. O., Fyllas, N. M., Schwarz, M., and Czimczik, C. I.: Soils of Amazonia with particular reference to the RAINFOR sites, Biogeosciences, 8, 1415-1440, doi:10.5194/bg-8-1415-2011, 2011.

R Development Core Team: R: A language and environment for statistical computing. R Foundation for Statistical Computing, Vienna, Austria, ISBN 3-900051-07-0, 2012.

Ratnam, J., Bond, W. J., Fensham, R. J., Hoffmann, W. A., Archibald, S., Lehmann, C. E., Anderson, M. T., Higgins, S. I., and Sankaran, M.: When is a "forest"a savanna, and why does it matter?, Global Ecol. Biogeogr., 20, 653-660, 2011.

Ratter, J.: Transition between cerrado and forest vegetation in Brazil, in: Nature and Dynamics of Forest-Savanna Boundaries, edited by: Furley, P., Proctor, J., and Ratter, J. A., Chapman and Hall, London, 417-430, 1992.

Ribeiro, S. C., Fehrmann, L., Soares, C. P. B., Jacovine, L. A. G., Kleinn, C., and de Oliveira Gaspar, R.: Above-and belowground biomass in a Brazilian Cerrado, Forest Ecol. Manag., 262, 491499, 2011.

Ryan, M. G. and Yoder, B. J.: Hydraulic limits to tree height and tree growth, Bioscience, 47, 235-242, 1997.

Ryan, M. G., Phillips, N., and Bond, B. J.: The hydraulic limitation hypothesis revisited, Plant Cell Environ., 29, 267-281, doi:10.1111/j.1365-3040.2005.01478.x, 2006.

Ryu, Y., Sonnentag, O., Nilson, T., Vargas, R., Kobayashi, H., Wenk, R., and Baldocchi, D. D.: How to quantify tree leaf area index in an open-savanna ecosystem: a multi-instrument and multi-model approach, Agr. Forest Meteorol., 150, 63-76, 2010.

Saiz, G., Bird, M. I., Domingues, T. F., Schrodt, F., Schwarz, M., Feldpausch, T. R., Veenendaal, E. M., Djagbletey, G., Hien, F., Compaore, H., Diallo, A., and Lloyd, J.: Variation in soil carbon stocks and their determinants across a precipitation gradient in West Africa, Glob. Change Biol., 18, 1670-1683, doi:10.1111/j.1365-2486.2012.02657.x, 2012.

Sankaran, M., Hanan, N. P., Scholes, R. J., Ratnam, J., Augustine, D. J., Cade, B. S., Gignoux, J., Higgins, S. I., Le Roux, X., Ludwig, F., Ardo, J., Banyikwa, F., Bronn, A., Bucini, G., Caylor, K. K., Coughenour, M. B., Diouf, A., Ekaya, W., Feral, C. J., February, E. C., Frost, P. G. H., Hiernaux, P., Hrabar, H., Metzger, K. L., Prins, H. H. T., Ringrose, S., Sea, W., Tews, J., Worden, J., and Zambatis, N.: Determinants of woody cover in African savannas, Nature, 438, 846-849, 2005.

Schimper, A. F. W.: Plant Geography upon a Physiological Basis (translated from the German by Fisher, W. R.), Clarendon Press, Oxford, 1903.

Schrodt, F., Domingues, T. F., Feldpausch, T., Saiz, G., Quesada, C. A., Schwarz, M., Ishida, F. Y., Compaore, H., Diallo, A., Djag- 
bletey, G., Hien, F., Hiernaux, P., Mougin, E., Sonk, B., Zapfack, L., Bird, M. I., Lewis, S. L., Meir, P., Phillips, O. L., Grace, J., Veenendaal, E., and Lloyd, J.: Foliar trait contrasts between African forest and savanna trees: Genetic versus environmental effects. , Funct. Plant Biol., 42, 63-83, doi:10.1071/FP14040, 2014

Schnitzer, S. A., DeWalt, S. J., and Chave, J.: Censusing and measuring lianas: a quantitative comparison of the common methods, Biotropia, 38, 581-591, 2006.

Silva, L. C., Hoffmann, W. A., Rossatto, D. R., Haridasan, M., Franco, A. C., and Horwath, W. R.: Can savannas become forests? A coupled analysis of nutrient stocks and fire thresholds in central Brazil, Plant Soil, 1-14, 2013.

Singh, L. and Singh, J.: Species structure, dry matter dynamics and carbon flux of a dry tropical forest in India, Ann. Bot.-London, 68, 263-273, 1991.

Skarpe, C.: Shrub layer dynamics under different herbivore densities in an arid savanna, Botswana, J. Appl. Ecol., 873-885, 1990.

Staver, A. C. and Hansen, M. C.: Analysis of stable states in global savannas: is the CART pulling the horse? a comment, Global Ecol. Biogeogr., 23, 259-263, 2015.

Staver, A. C., Archibald, S., and Levin, S.: Tree cover in sub-Saharan Africa: rainfall and fire constrain forest and savanna as alternative stable states, Ecology, 92, 1063-1072, doi:10.1890/10-1684.1, 2011a.

Staver, A. C., Archibald, S., and Levin, S. A.: The global extent and determinants of savanna and forest as alternative biome states, Science, 334, 230-232, doi:10.1126/science.1210465, $2011 \mathrm{~b}$.

Sterck, F. J., Van Gelder, H. A., and Poorter, L.: Mechanical branch constraints contribute to life-history variation across tree species in a Bolivian forest, J. Ecol., 94, 1192-1200, doi:10.1111/j.13652745.2006.01162.x, 2006.

Swaine, M. D., Hawthorne, W. D., and Orgle, T. K.: The effects of fire exclusion on savanna vegetation at Kpong, Ghana, Biotropia, 24, 166-172, doi:10.2307/2388670, 1992.

Terpstra, J. T. and McKean, J. W.: Rank-based analysis of linear models using R, J. Stat. Softw., available at http://www.jstatsoft. org/v14/i07, 2005.

Thompson, J., Viana, J., Proctor, J., and Ratter, J.: Contrasting forest-savanna boundaries on Maraca Island, Roraima, Brazil, in: Nature and Dynamics of Forest-Savanna Boundaries, edited by: Furley, P., Proctor, J., and Ratter, J. A., Chapman and Hall, London, 367-391, 1992.

Torello-Raventos, M., Feldpausch, T., Veenendaal, E., Schrodt, F., Saiz, G., Domingues, T. F., Djagbletey, G., Ford, A., Kemp, J., Marimon, B. S., Marimon Junior, B. H., Lenza, E., Ratter, J. A., Maracahipes, L., Sasaki, D., Sonké, B., Zapfack, L., Taedoumg, H., Villarroel, D., Schwarz, M., Quesada, C. A., Ishida, F. Y., Nardoto, G. B., Affum-Baffoe, K., Arroyo, L., Bowman, D. M. J. S., Compaore, H., Davies, K., Diallo, A., Fyllas, N. M., Gilpin, M., Hien, F., Johnson, M., Killeen, T. J., Metcalfe, D., Miranda, H. S., Steininger, M., Thomson, J., Sykora, K., Mougin, E., Hiernaux, P., Bird, M. I., Grace, J., Lewis, S. L., Phillips, O. L., and Lloyd, J.: On the delineation of tropical vegetation types with an emphasis on forest/savanna transitions, Plant Ecol. Divers., 6, 101-137, doi:10.1080/17550874.2012.762812, 2013. van Gelder, A., Poorter, L. and Sterck, F. J.: Wood mechanics, allometry, and life-history variation in a tropical rain forest tree community, New Phytol., 87, 1289-1301, 2006.

Van Langevelde, F., Van De Vijver, C. A., Kumar, L., Van De Koppel, J., De Ridder, N., Van Andel, J., Skidmore, A. K., Hearne, J. W., Stroosnijder, L., and Bond, W. J.: Effects of fire and herbivory on the stability of savanna ecosystems, Ecology, 84, 337-350, 2003.

Walter, H. and Mueller-Dombois, D.: Ecology of Tropical and Subtropical Vegetation, Oliver \& Boyd, Edinburgh, UK, 1971.

Warman, L. and Moles, A. T.: Alternative stable states in Australia's Wet Tropics: a theoretical framework for the field data and a field-case for the theory, Landscape Ecol., 24, 1-13, 2009.

Warton, D. I., Duursma, R. A., Falster, D. S., and Taskinen, S.: smatr 3- an $\mathrm{R}$ package for estimation and inference about allometric lines, Methods in Ecology and Evolution, 3, 257-259, 10.1111/j.2041-210X.2011.00153.x, 2012

Werger, M. J. A.: Vegetation Structure in the Southern Kalahari, J. Ecol., 66, 933-941, doi: 10.2307/2259305, 1978.

White, D. A. and Hood, C. S.: Vegetation patterns and environmental gradients in tropical dry forests of the northern Yucatan Peninsula, J. Veg. Sci., 15, 151-160, doi:10.1111/j.16541103.2004.tb02250.x, 2004.

Williams, R. J., Zerihun, A., Montagu, K. D., Hoffman, M., Hutley, L. B., and Chen, X.: Allometry for estimating aboveground tree biomass in tropical and subtropical eucalypt woodlands: towards general predictive equations, Aust. J. Bot., 53, 607-619, 2005.

Wood, S. N.: Generalized Additive Models: an Introduction with R, Chapman \& Hall, 2006.

Zanne, A. E., Lopez-Gonzalez, G., Coomes, D. A., Ilic, J., Jansen, S., Lewis, S. L., Miller, R. B.,Swenson, N. G., Wiemann, M. C., and Chave, J.: Data from: Towards a worldwide wood economics spectrum, edited, Dryad Data Repository, doi:10.5061/dryad.234, 2009.

Zhang, Y., Chen, J. M., and Miller, J. R.: Determining digital hemispherical photograph exposure for leaf area index estimation, Agr. Forest Meteorol., 133, 166-181, 2005. 